\title{
Back to (non-)Basics: An Update on Neutral \& Charge-Balanced Glycosidase Inhibitors
}

Michela I. Simone, ${ }^{1, *}$, Laura J. Mares ${ }^{1}$, Clothilde A. Eveleens ${ }^{1}$, Adam McCluskey ${ }^{1}$, Brighid B. Pappin $^{2}$, Milton J. Kiefel ${ }^{2}$ and Todd A. Houston ${ }^{2, *}$

${ }^{1}$ Discipline of Chemistry, School of Environmental and Life Sciences, University of Newcastle, University Drive, Callaghan, NSW 2308, Australia

${ }^{2}$ Institute for Glycomics and School of Natural Sciences, Griffith University, Gold CoastCampus, Southport, QLD 4222, Australia

\footnotetext{
Abstract: Glycosidases have important anti-cancer, anti-viral and anti-diabetic properties.

This review covers the literature in the past 15 years since our initial review in this journal on "neutral" glycosidase inhibitors lacking a basic nitrogen found in iminosugars and azasugars or inhibitors that are neutral by virtue of being "charge-balanced" (zwitterionic). These structurally diverse inhibitors include lactones, lactams, epoxides such as cyclophellitol, and sulfonium ion derivatives of the natural product salacinol. Synthetic efforts toward cyclophillitol, salicinol and derivatives are also highlighted. Importantly, certain metals can inhibit glycosidases and care must be taken to remove residual catalysts from synthetic material to be tested against these enzymes.
} 


\section{Introduction}

Glycosidases (EC3.2.1-) are a large family of hydrolase enzymes crucial to metabolism and cellular function across the full breadth of living organisms. Glycosidase inhibitors represent an important family of medicinal agents encompassing numerous classes of alkaloids, the largest one of which is the iminosugars. These are considered carbohydrate analogues where the endocyclic oxygen is replaced with an amine and are further sub-classified into five main heterocyclic ring systems: piperidine, pyrrolidine, indolizidine, pyrrolizidine, and nortropane. Nojirimycin (NJ), a piperidine-based iminosugar, was the first natural sugar mimic to be discovered and its 1-deoxy congener (1-DNJ) is recognised a privileged structure and contained in several marketed clinical agents (Figure 1). While 1-DNJ is not particularly basic $\left(\mathrm{pK}_{\mathrm{aH}}=6.7\right),{ }^{1}$ it can deprotonate a catalytic carboxylic acid within the glycosidase active site to form a strong complementary electrostatic interaction with the anionic environs that are present in the glycosidase hydrolytic site. Glycosidases have evolved specialised active sites designed to lower the energy barrier for glycosidic bond hydrolysis and consequently increase this reaction rate by a factor of more than $10^{17}$ through transition state stabilisation and substrate distortion. ${ }^{2-15}$

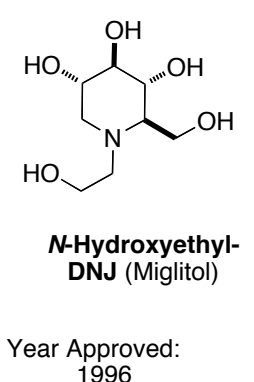
1996<smiles>OCC1=CCC(NP)C(O)C1O</smiles>

$$
\mathrm{R}=\mathrm{a} \text { trisaccharide }
$$$$
\begin{gathered}
\text { Year Approved: } \\
1995
\end{gathered}
$$

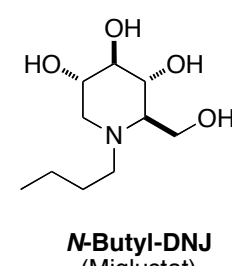
(Miglustat)

2003<smiles>CCOC(=O)C1=CC(N)C(N=[W])C(OCC)C1</smiles>

Oseltamivir 1999<smiles>OCC(CO)NC1CC(O)(O)C(O)C(O)C1O</smiles>

1995

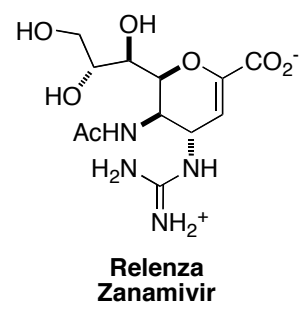

1999

Figure 1. Small molecule glycomimetics marketed as clinical agents for management of diabetes (Miglitol, Voglibose and Acarbose), Gaucher disease (Miglustat), and influenza (Oseltamivir, Zanamivir). 
Glycosidases (EC3.2.1-) can cleave oligosaccharides at internal glycoside linkages (carried out by endo-glycosidases such as amylase and lysozyme) or more commonly at the nonreducing terminal sugar residue (carried out by exo-glycosidases). Generally, these enzymes are glycoside hydrolases that operate by one of two mechanisms either inverting or retaining the anomeric stereochemistry on replacement of the glycosidic bond with water to produce a reducing sugar (Scheme 1). Retaining enzymes place an acidic group in close proximity to the exo-anomeric oxygen and a nucleophile poised to attack the anomeric carbon to produce a glycosyl-enzyme intermediate. Attack of water then occurs through a virtually identical transition state thus receiving similar stabilization from the active site residues. The vast majority of these active site pairs are carboxylic acids (aspartate/glutamate) spaced roughly $5.5 \AA$ apart. Inverting enzymes stretch the distance between active site carboxylates to roughly $10 \AA$ such that one carboxylate can deprotonate a water molecule to displace the glycosidic bond in a single step as shown. ${ }^{2}$

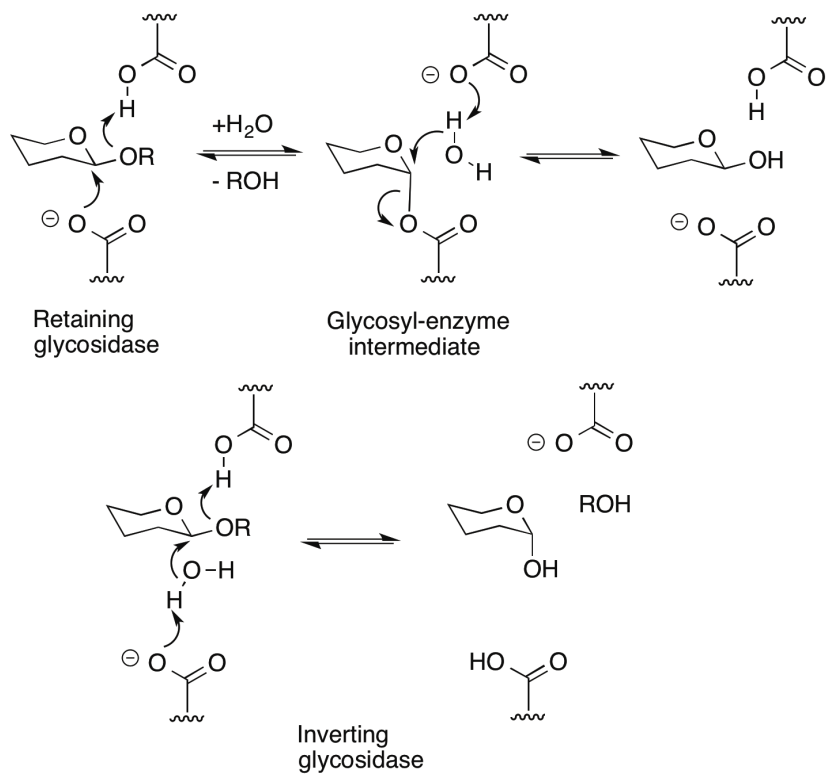

Scheme 1. General mechanisms of retaining and intverting glycosidases.

Significant insight to inhibitor design has been provided in the past 15 years from X-ray crystallography of a variety of inhibitors bound to glycosidases. Protonation states of both glycosidases and putative transition-state mimics provide crucial data to inform drug design strategies. ${ }^{16}$ An illustrative example was reported by Davies that permitted direct observation of a protonated isofagomine derivative in co-crystallised the active site of an endocellulase (EC 3.2.1.4). ${ }^{17}$ This same compound occupies the active site of a cellobiohydrolase (EC 3.2.1.91) in an unusual boat conformation demonstrating the diverse conformational profile of both glycomimetics and natural sugar substrates. ${ }^{18}$ Thus, the conformational flexibility of 
iminosugars and other glycomimetics demands a more complete understanding of enzyme binding if optimal inhibitors are to be developed. ${ }^{19}$ Use of thermodynamic and kinetic analysis in concert with structural studies provides a greater understanding of substrate transition-state mimicry and can allow identification and development of novel classes of inhibitors. ${ }^{20}$ Natural abundance kinetic isotope effect studies have been used to compare similarities and differences between acid- and enzyme-catalyzed glucoside hydrolysis of both anomeric configurations. ${ }^{21}$ While this evidence suggests the $\alpha$-glucosidase reaction involves a $\mathrm{D}_{\mathrm{N}} * \mathrm{~A}_{\mathrm{N}}\left(\mathrm{S}_{\mathrm{N}}{ }^{1}\right.$-type $)$ mechanism, the $\beta$-glucosidase mechanism appears to undergo a concerted $\mathrm{A}_{\mathrm{N}} \mathrm{D}_{\mathrm{N}}\left(\mathrm{S}_{\mathrm{N}}^{2}\right)$ pathway.

While iminosugars remain currently the most abundant class of glycosidase inhibitors in development, ${ }^{22-37}$ research into other molecular scaffolds has provided new classes of lead compounds. Neutral (non-ionized at physiologic $\mathrm{pH}$ ) and charge-balanced (zwitterionic at physiologic $\mathrm{pH}$ ) glycosidase inhibitors were the subject of our initial review in $2003 .{ }^{38}$ Examples include the neutral D-glucono- $\delta$-lactone (gluconolactone) $\mathbf{1}$ and (+)-cyclophellitol 2 and the zwitterionic salacinol $\mathbf{3}$ and recent FDA approved neuraminidase inhibitor peramivir 4 (Figure 2).

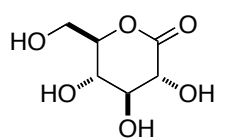

D-Glucono- $\delta$-lactone 1

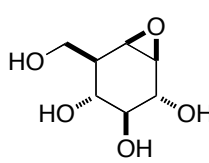

(+)-Cyclophellitol 2

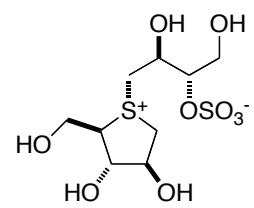

Salacinol 3

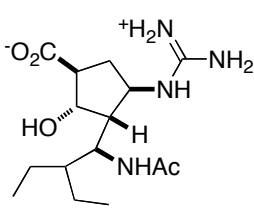

Peramivir 4

Figure 2. Chemical structures of "neutral" (1 and 2) and "charge-balanced" (3 and 4$)$ glycosidase inhibitors.

An increased understanding of the intricacies of glycosidase-inhibitor interaction over the past decade has provided opportunites for further improving drug design. Antidiabetic drugs such as miglitol and acarbose and the influenza drugs zanamivir (Relenza) and oseltamivir (Tamiflu) demonstrate the biological impact of glycosidase inhibition (Figure 1). ${ }^{39}$ Lactams derived from glucuronic acid possess potent anticancer activity presumably by inhibition of glycosidases such as heparanase. ${ }^{40,41}$ Inhibitors such as cyclophellitol 2 have served as foundation for the development of acylaziridines as potent activity-based probes of human galactosidases. ${ }^{42}$ As such, we felt it was appropriate to provide updated review of work on glycosidase inhibitors beyond iminosugars and their congeners, which had already provided several agents to reach the market at the time of our previous review (Figure 2) ${ }^{37}$ 
This review examines new lactone, lactam, epoxide, polycyclic aromatic hydrocarbon and sulfonium ion inhibitors of principally exo-glycosidases: glucosidase, mannosidase, galactosidase and fucosidase enzymes. At the time of our previous review, many of the most potent glycosidase inhibitors had $\mathrm{K}_{\mathrm{i}}$ values in the low micromolar to high nanomolar range. However, in the past decade several nanomolar inhibitors have been identified and one exceptionally potent inhibitor now operates in the picomolar range. ${ }^{43}$ In terms of a quantitative classification of inhibitory potencies towards glycosidases, we use as a guide the following bands: a weak inhibitor possesses $\mathrm{IC}_{50}$ value above $250 \mu \mathrm{M}$, moderate inhibition for 100-249 $\mu \mathrm{M}$, good for $10-99 \mu \mathrm{M}$, potent for $0.1-9 \mu \mathrm{M}$ and very potent for inhibition under $0.1 \mu \mathrm{M}$. As sugar lactones (e.g. 1) were the first glycosidase inhibtors identified in the 1940's, these are a fitting starting point for this review. ${ }^{38}$

\section{Lactones, Lactams, and Derivatives}

Gluconolactone 1 continues to find application today as it was shown to block the glucanase activity of Gram negative bacteria binding proteins in termites as a means of pest control. ${ }^{44}$ One pharmacological disadvantage of lactones is their susceptibility to hydrolysis, which makes them unlikely to provide suitable leads for potential human therapies. However, lactams are a more hydrolytically robust and useful family of glycosidase inhibitors due to their close relationship to the iminosugar class of natural products. The reduced basicity of the nitrogen means these derivatives will not protonate as readily as iminosugars within the glycosidase active site. Direct comparison of lactams and the iminosugars from which they are derived has provided useful insight into glycosidase binding mechanisms and the extent of transition state mimicry as outlined below.

In 2004, Davies and co-workers reported an X-ray crystallography study of lactam 9 bound in the active site of both $\beta$-glucosidases and $\beta$-mannosidases which aided the understanding of differences in substrate binding by these related exo-glycosidases (Figure 3). The $\beta$ glucosidase $T m \mathrm{GH} 1$ and $\beta$-mannosidase $C m$ Man5 distort their substrates into either a halfchair or boat-like conformation, respectively. ${ }^{45}$ Lactam $\mathbf{5}$ is able to adopt conformations that conform to either transition state structure depending on the predisposition of the active site. The lactam derivatives of iminosugars can serve as more effective transition state analogues than their parent structures has been demonstrated by Withers for the xylanase Cex. ${ }^{45}$ While inhibitor 5 and its analogue 6 have similar $K_{i}$ values $(0.33$ vs $0.13 \mu \mathrm{M})$, they would be expected to display significantly different pharmacologic profiles due to lack of a basic 
secondary amine in 5. A related study into analogous imidazole-containing inhibitors of glucosidases and mannosidases identified manno-imidazoles $\mathbf{7}$ and $\mathbf{8}$ as potent inhibitors of $\alpha$ mannosidase (Jack bean, $\mathrm{K}_{\mathrm{i}}=0.75$ and $1.22 \mu \mathrm{M}$ ) and excellent selectivity in inhibition of $\beta$ mannosidase (snail, $\mathrm{K}_{\mathrm{i}}=0.12$ and $138 \mu \mathrm{M}$ ). This latter effect was accounted for by the extensive protonation of both $\mathbf{7}$ and $\mathbf{8}$ at the low $\mathrm{pH}$ of the assay for this enzyme $(\mathrm{pH}=4.0$ 4.5), resulting in the formation of, respectively, the imidazolium salt of 7 and an equilibrium mixture of the corresponding ammonium/imidazolinium salts of $\mathbf{8}$. The formation of the ammonium salt is expected to impair the interaction between the inhibitor and the catalytic acid. ${ }^{46}$ Two mannosidase enzymes are of relevance to mammalian glycoprotein processing. ${ }^{44}$, 47-49 The natural product lactam kifunensine 9 inhibits $\alpha$-mannosidase I and has been used to allow crystallization of a cytotoxic T-lympocyte antigen by restricting processing of its glycan structures. ${ }^{50}$ Pearson reported a practical synthesis of kifunensine 9 ( $\mathrm{IC}_{50}=<0.03$ [mannosidase I (endoplasmatic reticulum, ER)] and $<0.03 \mathrm{mM}$ [mannosidase IA (mouse, Golgi)]) and derivatives, where N-1 substitution correlated with an improved selectivity profile of mannosidase I vs mannosidase IA for this class of analogues, albeit at the cost of loss of potency. For example, 10 inhibits the enzymes with $\mathrm{IC}_{50} \mathrm{~s}=0.08$ and $0.17 \mathrm{mM}$ respectively, 11 exhibiting the greatest selectivity with $\mathrm{IC}_{50} \mathrm{~s}=0.03$ and $0.15 \mathrm{mM}$, and 12 with $\mathrm{IC}_{50 \mathrm{~S}}=0.2$ and $2.1 \mathrm{mM} .{ }^{51}$ Introduction of a lactam moiety and a geminal difluoromethylene group on trihydroxy-2-thiaquinolizidines affords difluorotetrahydropyridothiazinone (not shown) with improved selectivity in glycosidase inhibition and an $\mathrm{IC}_{50}$ of $2.01 \mu \mathrm{M}$ against $\beta$ galactosidase (E. coli).$^{52}$ As a caveat, it should be noted that some lactam derivatives of natural iminosugars have dramatically diminished glycosidase inhibition profiles and such substitution is not always warranted..$^{53}$ 
<smiles>O=C1NCC[C@H](O[C@H]2OCC(O)[C@H](O)C2O)[C@H]1O</smiles><smiles>N[C@H]1c2nccn2C(CO)[C@@H](O)C1O</smiles>

8<smiles>OC1COC(O[C@@H]2CCNCC2O)C(O)C1O</smiles><smiles>[R]N1C(=O)C(=O)N2C(CO)[C@H](O)C(O)[C@H](O)[C@H]12</smiles>

$\mathrm{R}=\mathrm{H}, 9$

$\mathrm{R}=\mathrm{Me}, 10$

$\mathrm{R}=-\mathrm{CH}\left(\mathrm{CH}_{2} \mathrm{OH}\right)_{2}, \mathbf{1 1}$<smiles>OCC1[C@H](O)C(O)C(O)c2nccn21</smiles>

7

Figure 3. Lactam 5 and amine analogue $6,{ }^{45}$ manno-imidazoles 7 and $8,{ }^{46}$ the natural product kifunensine 9 and their analogues (10-12) as glycosidase inhibitors. ${ }^{51,54}$

Carbamate derivatives 15-18 (Figure 4) of the natural bicyclic alkaloid australine 14 and its monocyclic version $(2 R, 3 R, 4 R, 5 R)$-2,5-hydroxy-methyl-3,4-dihydroxypyrrolidine (DMDP) 13 display selective glycosidase inhibition profiles (Table I) over that of DMDP, whilst still retaining similar potency. For example, $\mathbf{1 5}$ is selective for $\beta$-glucosidase (almonds) and isomaltase (yeast), and the more conformationally restricted australine analogues displayed increased selectivity with $\mathbf{1 6}$ for trehalase (pig kidney), 17 and $\mathbf{1 8}$ for isomaltase (yeast). The enzyme selectivity in this latter case seems to depend strongly on the degree of $\mathrm{sp}^{2}$ hybridisation of the bridgehead-N, with greater basicity of that $\mathrm{N}$ being correlated to decreased isomaltase inhibition (see 16 vs 17 and 18). ${ }^{55}$ Pandey has described an unusual $\beta$-lactam iminosugar derivative 19 with selective $\beta$-galactosidase inhibition $\left(\mathrm{K}_{\mathrm{i}}=172 \mu \mathrm{M}\right)$ in a panel of glycosidases ( $\beta$-galactosidase (Aspergillus oryzae), $\alpha$-galactosidase (coffee beans), $\beta$ glucosidase/ $\beta$-mannosidase (almonds), $\alpha$-glucosidase (yeast) and $\alpha$-mannosidase (jack beans)). ${ }^{56}$ 
<smiles>OCC1N[C@H](CO)C(O)[C@H]1O</smiles>

DMDP 13<smiles>OC[C@H]1C(O)[C@@H](O)[C@@H]2C(O)CCN12</smiles>

Australine 14<smiles>OCC1[C@@H](O)C(O)[C@@H](CO)N1C(=S)Nc1ccccc1</smiles>

15

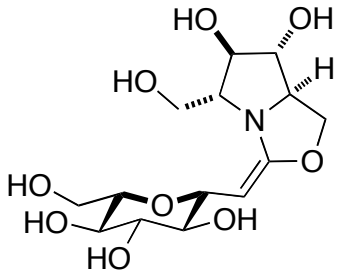

16<smiles>O=C1OC[C@H]2[C@@H](O)[C@H](O)[C@@H](CO)N12</smiles>

17<smiles>OC[C@H]1C(O)[C@@H]2COC(=S)N2[C@H]1O</smiles>

18<smiles>O=C1C[C@H]2C(O)C(O)C(O)CN12</smiles>

19

Figure 4. A range of natural products $(\mathbf{1 3}, \mathbf{1 4})$ and their analogues $(\mathbf{1 5 - 1 8})$ as glycosidase inhibitors $^{55}$ and constrained $\beta$-lactam iminosugar analogue 19. ${ }^{56}$

Table I. $K_{i}$ Values $(\mu \mathrm{M})$ of derivatives 15-18 and for the parent alkaloids DMDP 13 and australine 14 against various glycosidases. ${ }^{55}$

\begin{tabular}{|c|c|c|c|c|c|c|c|c|}
\hline ن & 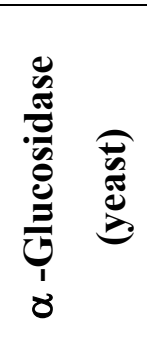 & 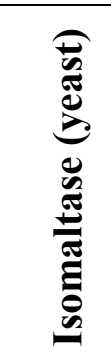 & 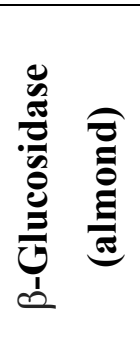 & $\begin{array}{l}\beta \text { - } \\
\text { Glucosidase/ } \\
\beta \text { - } \\
\text { Galactosidase } \\
\text { (bovine liver) }\end{array}$ & 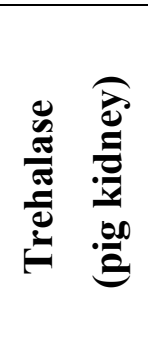 & 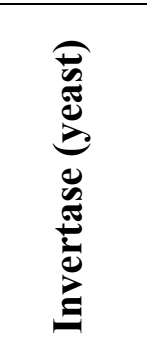 & 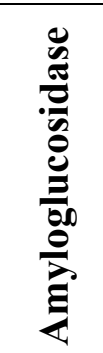 & 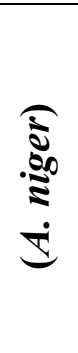 \\
\hline 13 & 0.73 & 2.5 & 1.7 & 3.3 & 355 & 2.9 & 2.1 & \\
\hline 14 & $\mathrm{NI}^{\mathrm{a}}$ & $\mathrm{ND}^{\mathrm{b}}$ & NI & ND & ND & 28 & 1.5 & \\
\hline 15 & 72 & 28 & 9.2 & 39 & NI & $>1000$ & NI & \\
\hline 16 & NI & 251 & NI & NI & 20 & NI & 249 & \\
\hline 17 & 132 & 29 & 340 & 644 & NI & NI & NI & \\
\hline 18 & 408 & 72 & 433 & 347 & NI & NI & NI & \\
\hline
\end{tabular}

${ }^{\mathrm{a}} \mathrm{NI}=$ no inhibition detected; ${ }^{\mathrm{b}} \mathrm{ND}=$ not determined.

\section{Hydantocidin analogues}

Many C-1, ${ }^{57-61} \mathrm{C}-2,{ }^{62,}{ }^{63} \mathrm{C}-3,{ }^{64-72}$ and C-473, 74 hydantoin derivatives (highlighted in red in 20, Figure 5) have been synthesised and biologically evaluated in the past 10-15 years. 
Representative examples of this class of glycosidase inhibitor are highlighted in Figure 5. The D-glucopyranose analogue $\mathbf{2 1}$ of hydantocidin $\mathbf{2 0}$ is a powerful competitive inhibitor of glycogen phosphorylase (GP) with respect to its natural substrate glucose-1-phosphate with a $\mathrm{K}_{\mathrm{i}}$ value of $3.1 \mu \mathrm{M}$, whereas the $\alpha$-epimer inhibits GP with a $\mathrm{K}_{\mathrm{i}}$ value of $28.6 \mu \mathrm{M}$ (Figure 5). ${ }^{75}$ Pal and Vankar synthesised the sugar-derived spiro-aminals 22, 23 and 24, 25 which were tested against five glycosidases [ $\alpha$-glucosidase (yeast), $\beta$-glucosidase (almonds), $\alpha$ galactosidase (coffee beans), $\beta$-galactosidase (bovine) and $\alpha$-mannosidase (Jack bean)] ${ }^{76}$ The most potent spiro-aminals were $\mathbf{2 2}$ and $\mathbf{2 4}$ which showed good inhibition against galactosidases, 24 against $\alpha$-galactosidase (coffee beans) with an $\mathrm{IC}_{50}$ of $77 \mu \mathrm{M}$ (nonselective), and 22 against $\beta$-galactosidase (selective, $\mathrm{IC}_{50}$ of $207 \mu \mathrm{M}$ ). Of the epimeric mannose-derived spiro-lactams 23 and 25,23 showed no activity against the tested enzymes, and 25 displayed only low levels of activity against $\beta$-galactosidase at $400 \mu \mathrm{M}$.

Commencing from a D-arabino-configured $\alpha$-azido ester template, Merino-Montiel et al., ${ }^{77}$ synthesised the first examples of C-3 spiro-annelated thiohydantoins and selenohydantoins (26-31; Figure 6). Thiohydantoins 26 and 27 exhibited weak to moderate, albeit selective, inhibition of GP (type b, rabbit muscle) (26; $\left.\mathrm{K}_{\mathrm{i}} 910 \mu \mathrm{M}\right)$ and $\alpha$-galactosidase (green coffee beans) $\left(27 ; \mathrm{K}_{\mathrm{i}} 160 \mu \mathrm{M}\right)$.

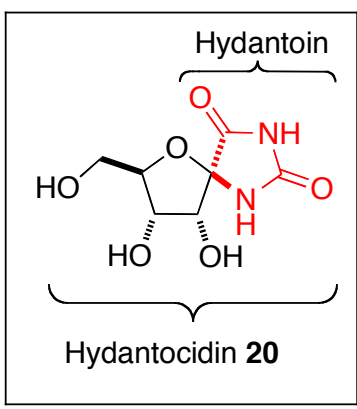<smiles>[R]N1C(=O)C2(NC(=S)NC2O)C(O)CO[C@H]1O</smiles>

$\mathrm{R}=\mathrm{Ph}, \mathbf{2 6}$

$\mathrm{R}=$ cyclohexyl, 27<smiles>O=C1N[C@]2(C(=O)NC(=O)C(O)[C@@H]2O)[C@H](O)O1</smiles>

21

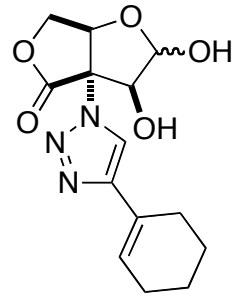

28<smiles>[R]C1CC(=O)NC12OC(CO)C(O)C(O)C2[R7]</smiles>

$\mathrm{R}^{1}=\mathrm{OH} ; \mathrm{R}^{2}=\mathrm{H}, 22$ $\mathrm{R}^{1}=\mathrm{H} ; \mathrm{R}^{2}=\mathrm{OH}, 23$<smiles>OCC1O[C@H](O)C(O)C2(CN=C(Nc3ccccc3)O2)C1O</smiles>

29<smiles>[R]C1CC(=O)NC12OC(CO)C(O)C(O)C2([R])[2H]</smiles>

$\mathrm{R}^{1}=\mathrm{OH} ; \mathrm{R}^{2}=\mathrm{H}, 24$ $\mathrm{R}^{1}=\mathrm{H} ; \mathrm{R}^{2}=\mathrm{OH}, 25$<smiles>[2H]NC1=NN[C@@]2(CN1)C(O)C(CO)O[C@H](O)C2O</smiles>

$\mathrm{R}=\mathrm{Ph}, \mathbf{3 0}$ $\mathrm{R}=\mathrm{Bn}, \mathbf{3 1}$

Figure 5. Natural product hydantocidin 20, hydantoin functional group highlighted in red. Hydantoin-based $(\mathbf{2 1})^{75}$ and hydantocidin analogues (22-27 $)^{76-78}$ evaluated as glycosidase inhibitors. 


\section{Salacinol and Derivatives}

Polyhydroxylated thiolane natural products, e.g. salacinol 3, are lead candidates for the treatment of Type 2 diabetes via $\alpha$-glucosidase inhibition (Figure 6). ${ }^{59,60,64,73,77-98}$ Herein we highlight some more recent developments in the field. Salacinol $\mathbf{3}$ is a potent competitive $\alpha-$ glucosidase inhibitor with $\mathrm{K}_{\mathrm{i}}$ values of 0.93 (rat intestinal maltase), 0.96 (rat intestinal sucrase), and 1.4 (rat intestinal isomaltase) $\mu \mathrm{M}$, respectively. ${ }^{85,99-101}$ The structurally related sulfonium sulfates, kotalanol 37, ${ }^{102}$ ponkoranol $39{ }^{103}$ and salaprinol $44{ }^{104}$ were subsequently isolated. In 2008, neosalacinol 32 and neokotalanol 38 lacking the 3'-sulfate moiety were isolated from Salacia oblonga and Salacia reticulata respectively. Neokotalanol $\mathbf{3 8}$ is the most potent glycosidase inhibitor among the naturally occurring sulfonium salts yet reported $\left(\mathrm{IC}_{50}\right.$ : maltase, $0.23 \mu \mathrm{M}$; sucrase $0.19 \mu \mathrm{M}) .{ }^{94,105}$ The permanent positive charge on the sulfate moiety mimics the oxacarbenium ion-like transition state of glycoside hydrolysis, allowing inhibition of a range of glycosidases. ${ }^{106-109}$ A number of structure-activity relationship studies, some of which are highlighted below, have shown that the 1,4-anhydro-4-thio-D-arabinitol (D-ATA) 48 core and the side-chain stereochemistries are important for inhibition (Scheme 6). ${ }^{101,110}$
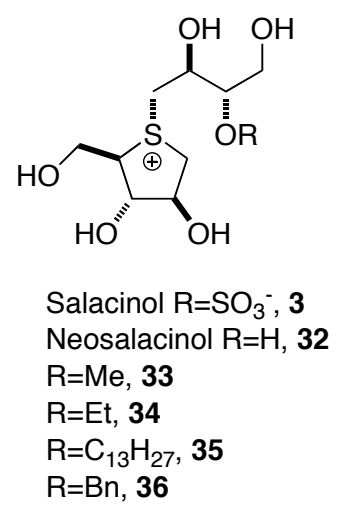

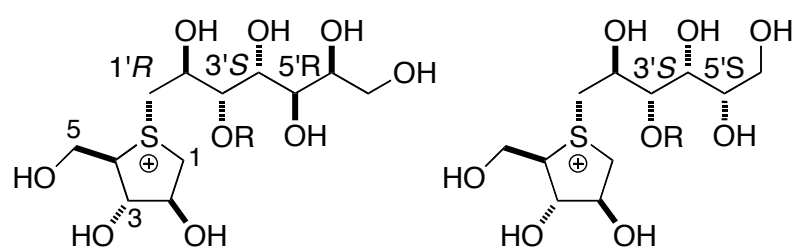

Kotalanol $\mathrm{R}=\mathrm{SO}_{3}^{-}, 37$ Neokotalanol $\mathrm{R}=\mathrm{H}, \mathbf{3 8}$
Ponkoranol $\mathrm{R}=\mathrm{SO}_{3}^{-}, 39$ Neoponkoranol $\mathrm{R}=\mathrm{H}, \mathbf{4 0}$ 5'R-epi-ponkoranol, 41 3'R-epi-ponkoranol, 42 3'-O-methylponkoranol, $\mathrm{R}=\mathrm{Me}, 43$

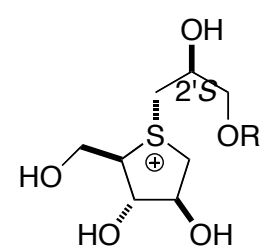

Salaprinol $\mathrm{R}=\mathrm{SO}_{3}^{-}, 44$ Neosalaprinol $\mathrm{R}=\mathrm{H}, 45$ 2'R-epi-salaprinol, 46 2'R-epi-neosalaprinol, 47

Figure 6. A range of polyhydroxylated-thiolanes as glycosidase inhibitors. ${ }^{85,93,94,99-105,111-114}$

The isolation of neoponkoranol 40 and neosalaprinol $\mathbf{4 5}$ from dried stems of Salacia chinensis, and the syntheses of their epimers (5'R-epi- 41 and $3^{\prime} R$-epi-ponkoranol $\mathbf{4 2}$, and $2^{\prime} R$ epi-salaprinol 46) was reported by Xie et al. ${ }^{11}$ The inhibition of $\alpha$-glucosidases (rat small intestinal) by this neo-series of compounds against was investigated in vitro and the outcomes highlighted in Table II.

Table II. $\mathrm{IC}_{50}$ Values $(\mu \mathrm{M})$ of thiosugar sulfonium salts and related compounds against $\alpha$ glucosidases. ${ }^{111}$ 


\begin{tabular}{|l|lll|}
\hline Compound & \multicolumn{3}{|c|}{$\boldsymbol{\alpha}$-Glucosidase (rat intestinal) } \\
\cline { 2 - 4 } & maltase & Sucrase & isomaltase \\
\hline $\mathbf{4 0}$ & 5.1 & 1.0 & 1.4 \\
$\mathbf{4 1}$ & 4.3 & 2.9 & 1.0 \\
$\mathbf{4 2}$ & 1.3 & 0.3 & 1.0 \\
$\mathbf{4 5}$ & $>384$ & 90 & 6.5 \\
$\mathbf{4 6}$ & $>329$ & $>329$ & $>329$ \\
$\mathbf{4 7}$ & 105 & $>384$ & 53 \\
Voglibose & $1.2^{\mathrm{b}}$ & $0.2^{\mathrm{b}}$ & $2.1^{\mathrm{b}}$ \\
Acarbose & $1.7^{\mathrm{a}}$ & $1.5^{\mathrm{a}}$ & $646^{\mathrm{a}}$ \\
\hline
\end{tabular}

${ }^{\mathrm{a} F r o m ~ r e f . ~} 115 .{ }^{\mathrm{b}}$ From ref. 113.

Neoponkoranol 40 was potent against the three enzymes tested, while 2'R-epi-neosalaprinol 47 inhibited both maltase and isomaltase more effectively than its sulfated analogue $2^{\prime} R$-episalaprinol 46 (Table II). In terms of structure-actvity relationships, the de- $O$-sulfonation analogues showed improved inhibition of isomaltase. 2'-Epimerization causes a marked decrease in its inhibitory activity against isomaltase, however the C-3' and/or C-5' configuration showed no significant influence on the inhibitory activity. Thus, in the ponkoranol series, all four compounds were potent inhibitors regardless of the presence of the C-3'-sulfate moiety and also of the C-3' and/or C-5' stereochemistry with 3'R-epi-ponkoranol 42 being the most potent, and showing almost the same inhibitory capability as voglibose against all enzymes.

The de- $O$-sulfonated analogue neokotalanol 38, ${ }^{112}$ which also belongs to the salacinol family, was isolated from Salacia reticulata Wight. ${ }^{116}$ Neokotalanol 38 is a potent $\alpha$ glucosidase inhibitor of rat intestinal maltase and sucrase $(0.23 \mu \mathrm{M}, 0.19 \mu \mathrm{M})$ and $0.01 \mu \mathrm{M}$ isomaltase inhibitor. The combined inhibitory activies of $\mathbf{3 8}$, salacinol $\mathbf{3}$ ( $\mathrm{IC}_{50}$ : maltase, 9.6 $\mu \mathrm{M}$; sucrase, $2.5 \mu \mathrm{M}$; isomaltase, $1.8 \mu \mathrm{M}$ ) and kotalanol 37 (IC $\mathrm{I}_{50}$ : maltase, $6.6 \mu \mathrm{M}$; sucrase, $1.4 \mu \mathrm{M}$; isomaltase, $4.5 \mu \mathrm{M}$ ), from the same plant genus contribute to reported activity of this plants extracts..$^{95,116}$ Neokotalanol $\mathbf{3 8}$ was also found to lower post-prandial glucose levels in vivo via maltose- and sucrose-loading tests on Wistar rats. ${ }^{127}$

Minami et al. investigated the inhibitory activities of five-membered sugar mimics toward glycogen-degrading enzymes and various glucosidases and found evidence that the side-chain sulfate plays an important role in the specificity of enzyme inhibition. ${ }^{93}$ Salacinol $\mathbf{3}$, neosalacinol 32 and core structure D-ATA 48 (Scheme 6) were not found to inhibit glycogen phosphorylase but the former two inhibit amylo-1,6-glucosidase ( $\mathrm{IC}_{50} 48$ and $16 \mu \mathrm{M}$ 
respectively) (Table III). Neosalacinol 32 is also a potent inhibitor of $\alpha$-glucosidase (rat intestinal isomaltase, $\left.\mathrm{IC}_{50} 0.64 \mu \mathrm{M}\right)$. On the other hand, salacinol 3 showed a much more potent inhibitory activity toward $\alpha$-glucosidase (rat intestinal maltase, $\mathrm{IC}_{50} 0.5 \mu \mathrm{M}$ ) in Caco-2 cell model system and $\alpha$-glucosidase (human lysosomal, $\mathrm{IC}_{50} 0.34 \mu \mathrm{M}$ ).

Table III. IC I0 $_{0}$ Values $(\mu \mathrm{M})$ of thiosugar sulfonium salts 3 and 32, and D-ATA 48 against $\alpha$ glucosidases. ${ }^{93}$

\begin{tabular}{|l|l|l|l|l|l|}
\hline Compound & \multicolumn{4}{|l|}{$\alpha$-Glucosidase } \\
\cline { 2 - 6 } & rice & $\begin{array}{l}\text { rat } \\
\text { maltase }\end{array}$ & $\begin{array}{l}\text { rat } \\
\text { isomaltase }\end{array}$ & $\begin{array}{l}\text { rat } \\
\text { sucrase }\end{array}$ & $\begin{array}{l}\text { human } \\
\text { lysosome }\end{array}$ \\
\hline $\mathbf{3}$ & 2.6 & 2.4 & 5.7 & 2.2 & 0.34 \\
$\mathbf{3 2}$ & 8.6 & 10 & 0.64 & 5.2 & 4.4 \\
$\mathbf{4 8}$ & 220 & 290 & 1000 & NI & NI \\
\hline
\end{tabular}

The synthesis and biological evaluation of 3'-O-alkylated derivatives of salacinol (e.g. 3336) and ponkoranol (e.g. 39) provide SAR data for chemical modifications at the $3^{\prime}-O$ position. Tanabe et al. produced analogues 33-36), where replacement of the sulfonate group with an alkyl/aromatic group increases $\alpha$-glucosidases inhibiton (Table IV). ${ }^{113}$ The benzylated derivative $\mathbf{3 6}$ is more potent than the currently marketed antidiabetics, voglibose and acarbose. This suggests that the introduction of a C-3' hydrophobic moiety may be a viable potency enhancement strategy for this class of inhibitors.

Table IV. IC $\mathrm{I}_{50}$ Values $(\mu \mathrm{M})$ of 3'- $O$-alkylated salacinol derivatives 33-36 and positive controls voglibose and acarbose against $\alpha$-glucosidases. ${ }^{113}$

\begin{tabular}{|l|l|l|l|}
\hline Compound & \multicolumn{3}{|c|}{$\alpha$-Glucosidase (rat intestinal) } \\
\hline & maltase & isomaltase & sucrase \\
\hline $\mathbf{3 3}$ & 5.3 & 0.39 & 0.46 \\
$\mathbf{3 4}$ & 1.7 & 0.27 & 0.12 \\
$\mathbf{3 5}$ & 1.0 & 0.95 & 1.3 \\
$\mathbf{3 6}$ & 0.44 & 0.14 & 0.32 \\
Voglibose & 1.2 & 2.1 & 0.2 \\
Acarbose & $1.7^{\mathrm{a}}$ & $646^{\mathrm{a}}$ & $1.5^{\mathrm{a}}$ \\
\hline
\end{tabular}

${ }^{\mathrm{a}}$ From ref. 115. 
Eskandari et al. reported on the synthesis of 3'-O-methylponkoranol 43 (Figure 6) and biological evaluation against two $\alpha$-glucosidases (human intestinal maltase glucoamylase and sucrase isomaltase), which catalyse the final step of starch hydrolysis. ${ }^{114}$ These enzymes are located on the small intestinal brush border epithelial cells and contain two catalytic subunits, designated as the $\mathrm{N}$-terminal and the C-terminal subunits. 3'-O-Methylponkoranol $\mathbf{4 3}$ is a sub$\mu \mathrm{M}$ inhibitor of all the catalytic subunits, with $\mathrm{K}_{\mathrm{i}}$ for the C-terminal of maltase glucoamylase of $0.060 \mu \mathrm{M}$ and $0.055 \mu \mathrm{M}$ (two splice forms), and a 10-fold weaker inhibition for its $\mathrm{N}$ terminal of $0.50 \mu \mathrm{M}$. The $\mathrm{K}_{\mathrm{i}}$ value for the $\mathrm{N}$-terminal of sucrase isomaltase is of $0.035 \mu \mathrm{M}$, and a 5-fold selectivity enhancement is found at its C-terminal (7 $\mathrm{nM})$.

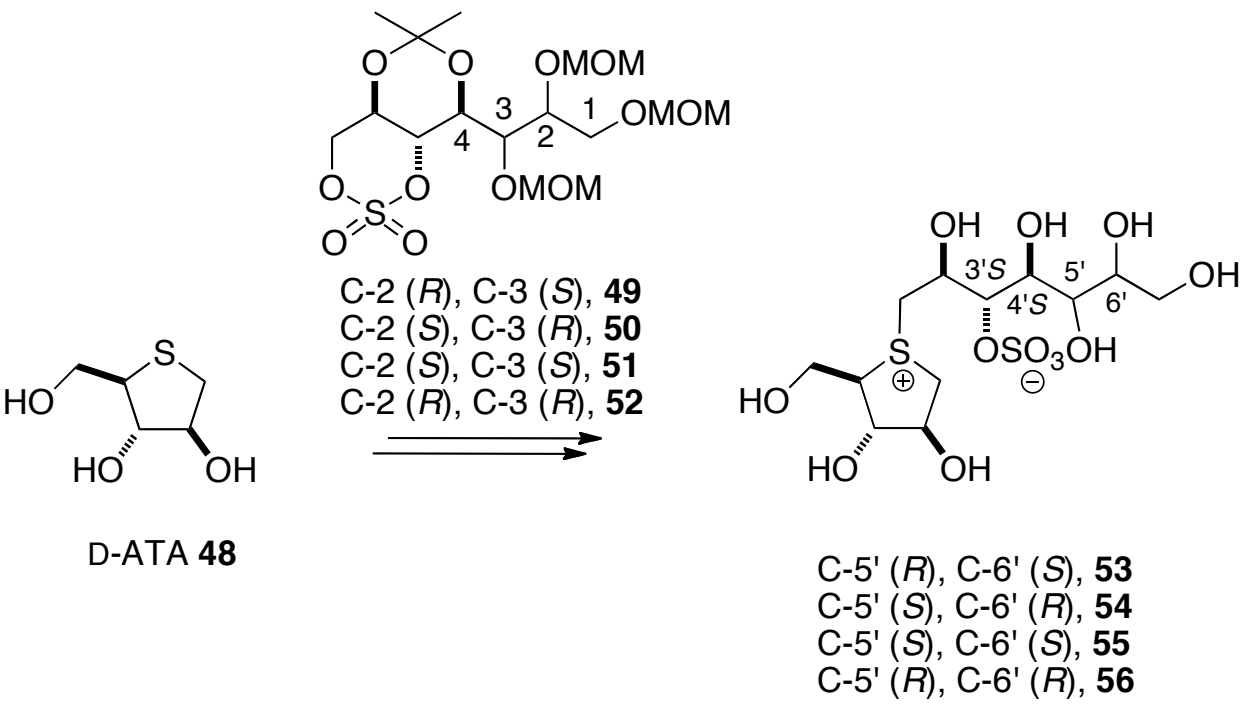

Scheme 2. Synthetic strategy by Tanabe for the synthesis of all C-5' and C-6' stereoisomers (53-56) of kotalanol 37..$^{117}$

Tanabe et al. completed the synthesis of a number of kotalanol $\mathbf{3 7}$ analogues examining the effect of side chain group stereochemistry changes. ${ }^{117}$ The four C-4' reversed configuration $(S)$ diastereomers (53-56) and all permutations of configuration at the C-5' and C-6' positions were accessed via coupling of D-ATA 48 with cyclic sulfates (49-52) to afford the sulfonium salts, which after deprotection afforded the desidered target salacinol analogues (53-56) (Scheme 2). Biological evaluation revealed two of the four diastereomers, 54 (IC 50 : maltase, $>236 \mu \mathrm{M}$; sucrose, $136 \mu \mathrm{M}$; isomaltase $11 \mu \mathrm{M}$ ) and $\mathbf{5 6}$ ( $\mathrm{IC}_{50}$ : maltase, $>236 \mu \mathrm{M}$; sucrose, $214 \mu \mathrm{M}$; isomaltase $16 \mu \mathrm{M}$ ) were significantly less active against both maltase and sucrase, while the other two, 53 (IC 50 : maltase, $49 \mu \mathrm{M}$; sucrose, $67 \mu \mathrm{M}$; isomaltase $1.6 \mu \mathrm{M}$ ) and $\mathbf{5 5}$ (IC 50 : maltase, $58 \mu \mathrm{M}$; sucrose, $32 \mu \mathrm{M}$; isomaltase $6.5 \mu \mathrm{M}$ ) essentially retained the inhibitory activity. Although all four diastereomers are potent inhibitors of isomaltase, the C-5' and 6'- 
$\mathrm{OH}$ stereochemistry seems to play an important role in determining selectivity in $\alpha$ glucosidase inhibition, with $\mathbf{5 4}$ and $\mathbf{5 6}$ showing enhanced selectivity for this enzyme. In silico docking studies of $\mathbf{5 4}$ and $\mathbf{5 6}$ and of parent compound kotalanol 37 with N-terminal subunit of human maltase-glucoamylase provided evidence for the fundamental requirement for the thiosugar moiety, with additional important determinants identified. Modelling supports that (a) the 2'-S-OH is essential for the activity; (b) a polyhydroxylated side chain longer than four carbons does not significantly enhance the inhibitory activity; (c) the cooperative role of 2 '-S$\mathrm{OH}$ and 4'-OH appears critical for optimal inhibition; and the $\mathrm{R}$ configuration of $\mathrm{OH}$ at $\mathrm{C}-4$ ' is imperative to inhibitors bearing a side chain of more than four carbons.

Liu and coworkers also coupled of D-ATA 48 with cyclic sulfates to access six carbon chain-extended analogues of salacinol $3,{ }^{118}$ with ring heteroatom variation to also include selenium. ${ }^{52,119}$ Four compounds were found to inhibit $\alpha$-glucosidase (recombinant human maltase glucoamylase), one of the key intestinal enzymes involved in the breakdown of glucose oligosaccharides in the small intestine, with low $\mu \mathrm{M} \mathrm{K}_{\mathrm{i}}$ values. The salacinol selenosugar analogue, $\mathbf{5 7}$, returned a $\mathrm{K}_{\mathrm{i}}$ value of $41 \mu \mathrm{M}$, while the corresponding sulfur analogue 58 is not active. Of the non-natural L-arabinitol configuration compounds 59 and $\mathbf{6 0}$, only the sulfur congener 60 is active, with a $K_{i}$ value of $25 \mu \mathrm{M}$ (Figure 7).

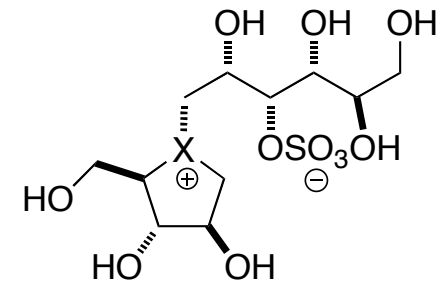

$X=\mathrm{Se}, 57$

$X=S, 58$

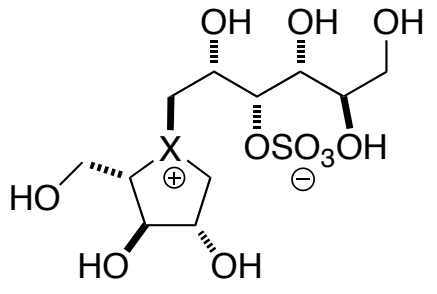

$X=S e, 59$

$X=S, 60$

Figure 7. Polyhydroxylated selenides and thiolanes as glycosidase inhibitors. ${ }^{118}$

Muroaka et al. synthesised salacinol analogues lacking the polar substituents in the side chain from reaction of D-ATA 48 with cyclic sulfates. ${ }^{120}$ Biological evaluation against $\alpha$ glucosidase (rat intestinal, maltase and sucrase) showed a marked decrease in inhibitory activity compared to salacinol. These results convey the importance of the cooperative role of the polar substituents in the side chain for the $\alpha$-glucosidase inhibitory activity. Other systems have been synthesized replacing a monosaccharide's ring oxygen with a sulfonium ion in the search for novel fucosidase inhibtors. ${ }^{121}$ 
Wolf and Weisbrode investigated the toxicological properties and safety of plant extracts from the Salacia oblonga supplemented to or processed into a medical food on male SpragueDawley rats. ${ }^{122}$ These were assigned among one of three treatments: (1) EN-0178 (control, liquid diet), (2) EN-0178+salacinol (as 1 plus $500 \mathrm{mg}$ of salacinol extract per $253 \mathrm{~g}$ diet, which was added to product immediately prior to feeding), (3) EN-0195 (as 1 plus $500 \mathrm{mg}$ of salacinol extract per $253 \mathrm{~g}$ diet, which was added during product manufacture). The tested salacinol extract consumed for two weeks in amounts estimated at 10-fold greater than proposed for human intake was found to be safe and did not result in clinical chemistry or histopathologic indications of toxic effects in male Sprague-Dawley rats. The rats had diarrhea (over the first four days) and reduced $(\mathrm{P}<0.05)$ weight gain and feed intake as salacinol extracts prevent complete digestion of dietary carbohydrate. ${ }^{123}$ Reduced feed efficiency ratio was also noted, and effects on the relative weight ( $\%$ of body weight) of the liver, spleen (lower $(\mathrm{P}<0.05)$ ) and testes (higher $(\mathrm{P}<0.05)$ ). Of the serum chemistries analyzed, blood urea nitrogen and alkaline phosphatase were lower $(\mathrm{P}<0.05)$ for rats consuming salacinol extract. No differences in blood hematology were found.

\section{Electrophilic Species}

Affinity-based probes and covalent inhibitors of glycosidases have been the subject of separate reviews recently. ${ }^{124,125}$ Herein we focus on epoxides, namely (+)-cyclophellitol 2 and its derivatives shown to act as irreversible inhibitors of $\beta$-glucosidases, and transition metal complexes which possess $\alpha$-glucosidase and $\alpha$-galactosidase inhibitory activity. Irreversible enzyme inhibitors such as epoxides have different pharmacological profiles to reversible enzyme inhibitors and in some cases are more effective at lower doses. Additionally, certain metals alone can inhibit glycosidases (vide infra) and may interfere with enzyme assays.

\subsection{Epoxides: Cyclophellitol and Related Cyclitols}

$(+)$-Cyclophellitol 2, a cyclitol analogue bearing an epoxide moiety on the $\beta$-face of the molecule, was isolated by Atsumi and coworkers from the mushroom Phellinus sp. (Figure 8). ${ }^{126,127}$ Biological evaluation against a panel of nine glycosidases revealed it to be a specific, competitive and irreversible inhibitor of $\beta$-glucosidase (almond, $50 \%$ inhibition at a $4.5 \mu \mathrm{M}$ concentration; with a $\mathrm{K}_{\mathrm{i}}$ of $2.8 \mu \mathrm{M}$ ). Furthermore, cyclophellitol inhibited $\beta$ glucocerebrosidase (Molt-4 cells) completely at $11 \mu \mathrm{M}$ with an inhibitory activity 100 times more potent than that of nojirimycin 61, 1-DNJ 62, or castanospermine 63. Mice treated with 1 
$\mathrm{mg} /$ mouse of cyclophellitol daily for five days exhibited severe nervous system abnormalities similar to those found in the Gaucher's mouse. X-ray crystallography, enzyme kinetics and mass spectrometry study revealed the structural basis for $\beta$-glucosidase inhibition by cyclophellitol as irreversible via nucleophilic opening of the epoxide moiety by the active site's Glu351 of $\beta$-glucosidase (Thermotoga maritima) and formation of a covalent bond. ${ }^{128}$

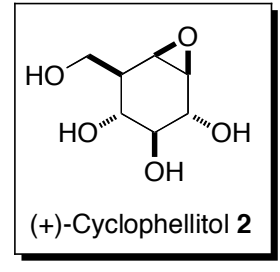<smiles>OCC1NC(P)C(O)C1O</smiles>

$\mathrm{R}=\mathrm{OH}$, Nojirimycin 61 $\mathrm{R}=\mathrm{H}, 1$-Deoxynojirimycin (1-DNJ) 62

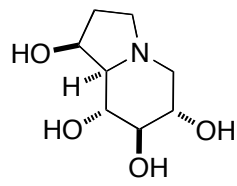

Castanospermine 63<smiles>OC1C=CC(O)C(O)C1O</smiles>

(+)-Conduritol F 64

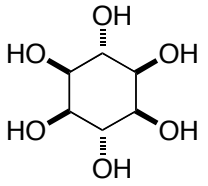

Muco-inositol 65

Figure 8. Structures of natural products that modulate glycosidase enzyme activity.

Synthetically, only two preparations of $(+)$-cyclophellitol from achiral precursors have been reported, ${ }^{129,130}$ while all other reports rely on carbohydrates as starting materials. ${ }^{131-137} \mathrm{~A}$ number of groups have used organometallic reactions to develop more efficient synthetic routes from carbohydrates. Notable is the work by Hansen and colleagues, ${ }^{138}$ who reported the shortest synthesis of cyclophellitol to date from D-xylose 66 in nine steps (14\% overall yield, Scheme 2). Key to Hansen's concise synthesis is three consecutive organometallic reactions: a zinc-mediated fragmentation of $\mathbf{6 7}$ affording 68, which upon indium-mediated coupling with the bromoester $\mathbf{6 9}$, gives $\mathbf{7 0}$ as a single diastereoisomer. In the third step, diene $\mathbf{7 0}$ was converted into the corresponding diene 71, precursor to the final product, by ring-closing metathesis via Grubbs II catalysis. Ishikawa et al. ${ }^{137}$ also used the zinc-mediated fragmentation strategy, but on a D-glucose derived substrate. Under Henry reaction conditions, the aldehyde adduct thus obtained afforded the corresponding epimeric nitroderivatives. These nitro-derivatives are converted into the corresponding cyclic nitronate intermediates and opened via reductive $\mathrm{N}-\mathrm{O}$ bond cleavage using of $\mathrm{Mo}(\mathrm{CO})_{6}{ }^{139}$ 


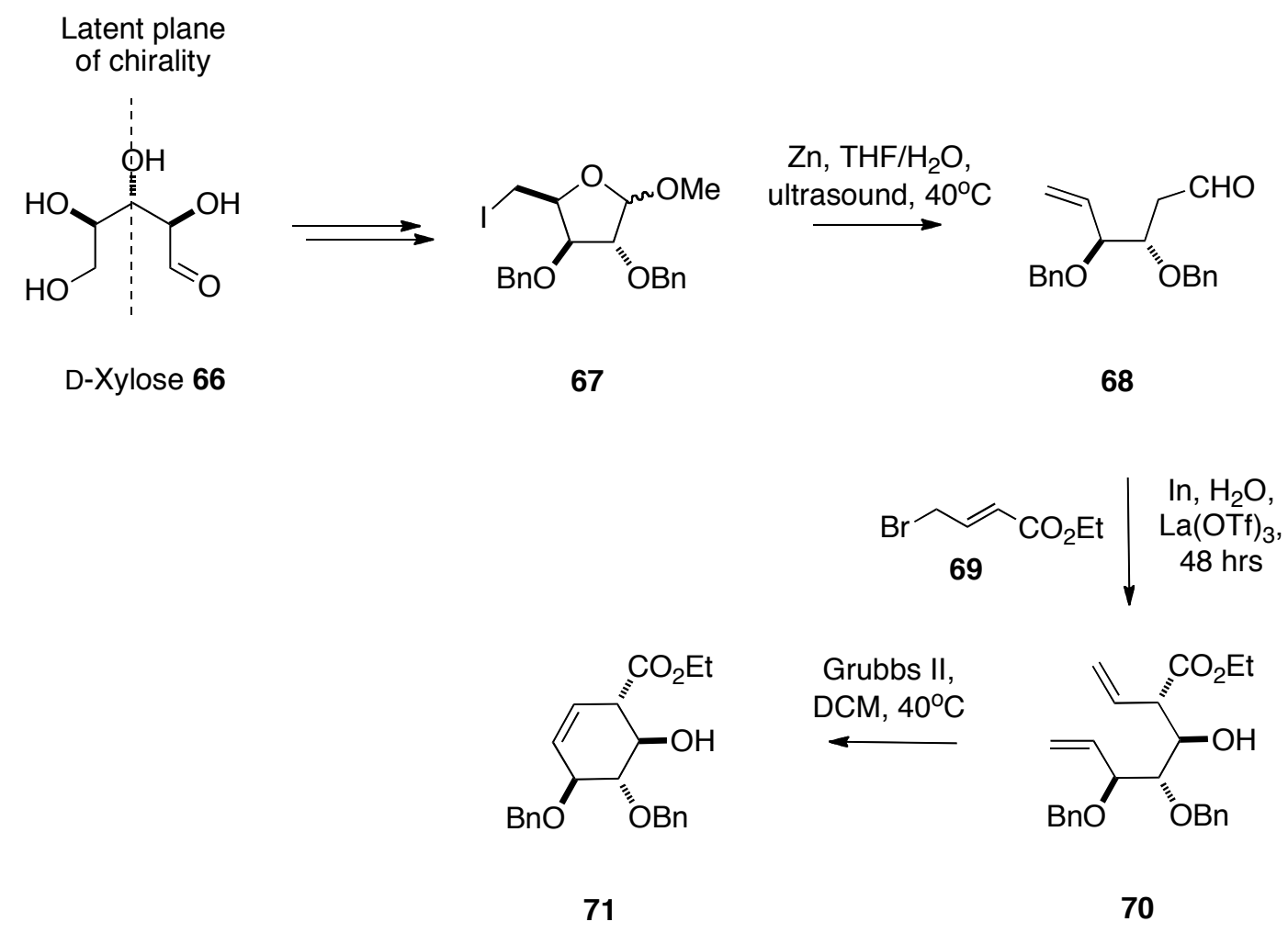

Scheme 3. Key steps in the synthetic strategy to cyclophellitol 2 devised by Hansen ${ }^{138}$ and, in Kireev's strategy, latent plane of symmetry highlighted on starting material $66 .{ }^{140}$

In a synthesis also starting from D-xylose 66, Kireev's strategy ${ }^{140}$ takes advantage of the latent symmetry principle (latent plane of chirality) ${ }^{141-143}$ of the monosaccharide (Scheme 3) to achieve the enantiodivergent synthesis of both (+)- and (-)-cyclophellitol in 12 and 15 steps with $18 \%$ and $13 \%$ overall yield, respectively. Serrano and coworkers investigated the hydroboration-oxidation sequence from precursor $\mathbf{7 2}$ and report the hydroboration step takes place with complete and opposite stereocontrol to that previously described in the literature (Scheme 4). ${ }^{144}$ This outcome was rationalized the bulky benzyloxy moiety driving the hydroborating agent approach to the less sterically hindered face, followed by $\mathrm{BCl}_{3}$ mediated debenzylation of $\mathbf{7 2}$ to afford the hitherto unreported (+)-5-epi-cyclophellitol $\mathbf{7 3}$.

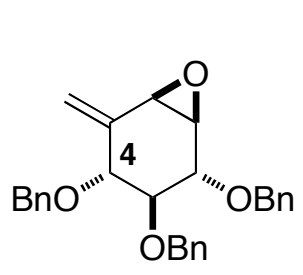

72 (i) $1 \mathrm{M} \mathrm{BH}_{3} \cdot \mathrm{THF}$, THF

(ii) $30 \% \mathrm{H}_{2} \mathrm{O}_{2}, 2 \mathrm{~N} \mathrm{NaOH}$, $\mathrm{THF} / \mathrm{H}_{2} \mathrm{O}(1: 1)(72 \%)$

(iii) $1 \overrightarrow{\mathrm{M} \mathrm{BCl}} \mathrm{Bn}_{3}$ heptane, DCM, $-78^{\circ} \mathrm{C}(98 \%)$.

Scheme 4. Reaction conditions and reagents for the key hydroboration-oxidation and deprotection steps in Serrano's synthetic strategy. ${ }^{144}$ 
Epoxy-inositol analogues, such as conduritol B epoxide (CBE, 1,2-anhydro-myo-inositol) 74, also irreversibly bind within the active site of glycosidases (Scheme 5, left). Premkumar and coworkers obtained an X-ray co-crystal of CBE 74 irreversibly bound to the acid- $\beta$ glucosidase (human) active site, with Glu340 as the catalytic nucleophile. ${ }^{145}$ The crystal structure data supports the proposed reaction mechanism, which requires protonation of the epoxide oxygen of CBE 74 by the catalytic acid/base pair, followed by nucleophilic attack at $\mathrm{C}-1$ of the cyclohexitol ring, causing diaxial opening of the epoxide and formation of a nucleophile-cyclohexitol ester bond shown in 75. ${ }^{145,146}$ The distance between C-1 of 75 and the Glu340 Oع2 is $1.43 \AA$, and the binding between 74 and the active site only involves Glu340. The distance between the epoxide oxygen of 74, oriented and the Glu235 Oe, is within H-bonding distance, which is consistent with the role of Glu235 as the acid/base catalyst.

Freeman and Hudlicky synthesized oligomers of (-)-conduritol-F 64 and muco-inositol 65 (Figure 8) as non-glycosidically labile oligosaccharide analogues, to exploit their rich combinatorial potential due to the additional chiral center of each monomer relative to their monosaccharide counterparts. ${ }^{147}$ These were evaluated against six glycosidases and compounds 76 (IC 50 : $\alpha$-galactosidase, $275 \mu \mathrm{M} ; \beta$-galactosidase, $250 \mu \mathrm{M})$ and $77\left(\mathrm{IC}_{50}: \alpha\right.$ glucosidase, $60 \mu \mathrm{M}$; $\beta$-galactosidase, $190 \mu \mathrm{M}$ ) that preserved the conduritol-F motif proved to be more potent inhibitors relative to the monomers or the muco-inositol dimer 78 ( $\mathrm{IC}_{50}$ : $\alpha$ glucosidase, $800 \mu \mathrm{M}$; $\beta$-galactosidase, $600 \mu \mathrm{M}$ ). The conduritol-F motif resembles more closely the structure of the transition state assumed to operate in glycolysis, ${ }^{146}$ and this may explain the higher inhibitory activity in comparison with the fully hydroxylated inositols.

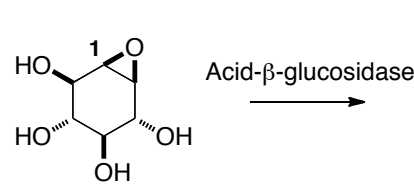

CBE 74

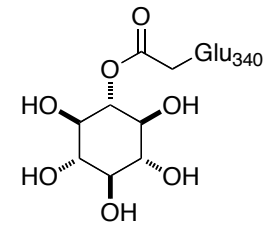

75

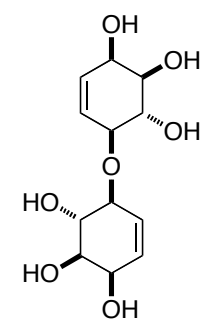

76

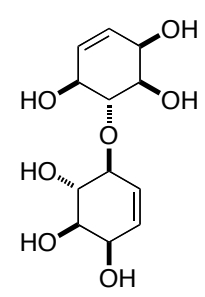

77

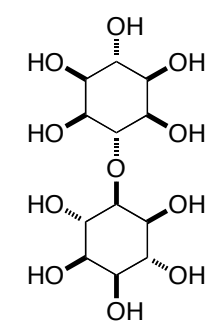

Muco-di-inositol 78

Scheme 5. (Left) Ester 75 is the adduct of the irreversible inhibition of acid- $\beta$-glucosidase via nucleophilic addition of active site's Glu340 to epoxy-inositol analogue CBE 74 to give 75. ${ }^{145}$ (Right) Conduritol- and inositol-based oligosaccharide analogues 76-78 as nonglycosidically labile oligosaccharide analogues. ${ }^{147}$ 
Witte and colleagues applied activity-based protein profiling (ABPP), more commonly used in the protease and esterase fields to the glycosidase field, to profiling of $\beta$-glucosidases in complex samples. The development of two cyclophellitol-based activity based probes $\mathrm{C} 1-$ BODIPYred 79 and C2-BODIPYgreen 80 were highly potent and selective for GBA-1 (Figure 9) permitted in vitro and in vivo visualization of these probes and the monitoring of wild-type and mutant GBA-1 activities. These studies offer the potential for critical insights into acid- $\beta$ glucosidase, GBA-1, in Gaucher's disease. ${ }^{148}$ Using C-6-azido cyclophellitol analogues followed by either a Staudinger-Bertozzi or Huisgen [3+2] click bio-orthogonal ligation with the C1-BODIPYred 79 and C1-BODIPYgreen 80 alkyne intermediates, to give C-1 and C-2 directly covalently bound to GBA-1. Experiments on isolated enzyme revealed that the ligation step is efficient, but a drop in in vitro efficacy was apparent on repeating the same experiments on cell extracts (which may possibly have been a permeability artefact).
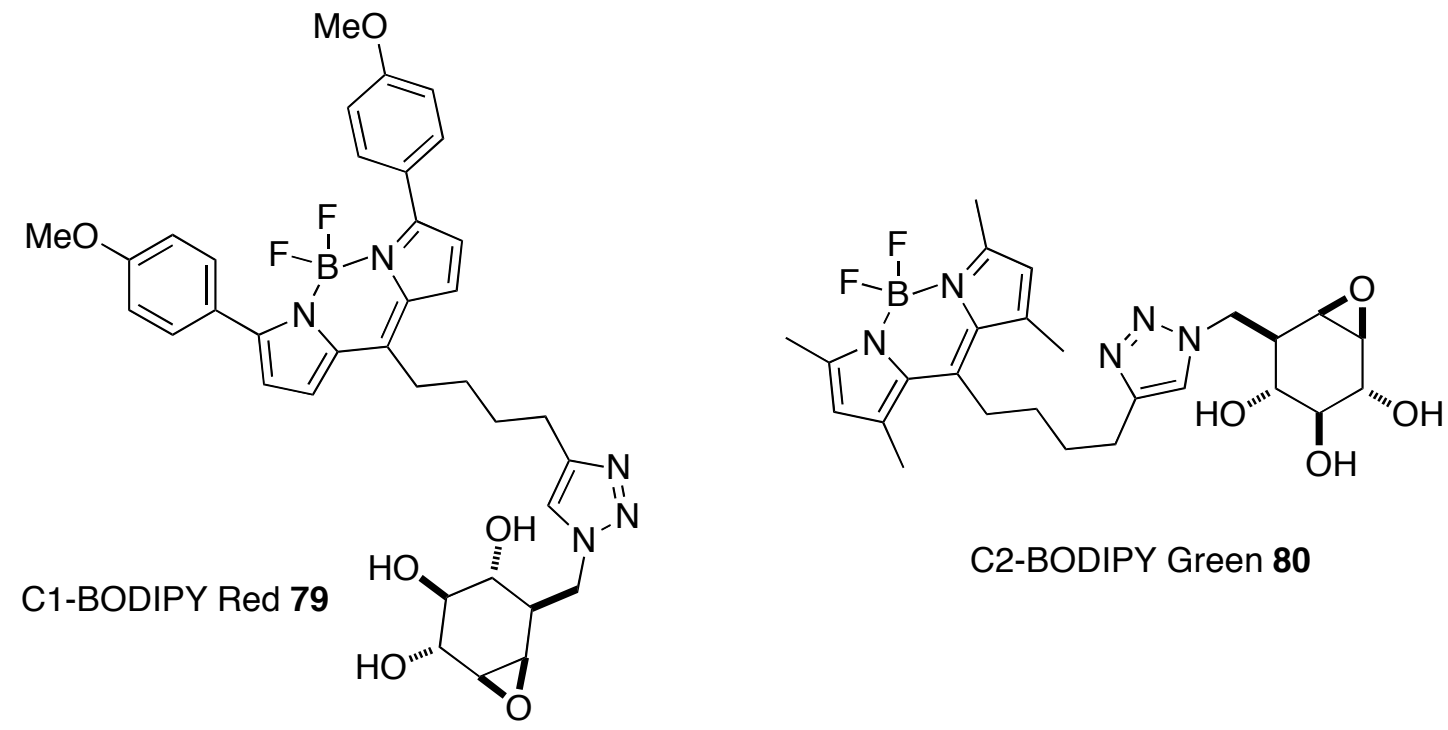

C2-BODIPY Green 80

Figure 9. Cyclophellitol-based BODIPY ABPP probes. ${ }^{148}$

Martínková et al. reported a chemo/enzymatic route to cyclophellitol and epi-cyclophellitol in enantiopure forms from racemic starting materials. ${ }^{149}$ The synthesis involves a multienzymatic resolution/biotransformation steps of the cyano-cyclitol intermediates $(1 R, 4 S, 5 R, 6 R) /(1 S, 4 R, 5 S, 6 S)-4,5,6$-trihydroxycyclohex-2-enecarbonitrile (rac)-81 by a cooperative use of lipase, nitrile hydratase, and amidase (Scheme 6). Preparation of the enantiomeric mixture of intermediate nitrile conduritol ( $\mathrm{rac}$ )-81 from inexpensive and available $p$-benzoquinone required five synthetic steps. Enantiomerically pure $(+)-\mathbf{8 1}$ was obtained after a lipase-catalysed resolution of $(\mathrm{rac})-\mathbf{8 1}$ in organic solvent to give intermediates $(+)-82$ and (-)-81, followed by chemical hydrolysis of (+)-82. The optimized resolution step employs lipase from Candida antarctica B or Rhizomucor miehei to afford the primary 
monoester product $(+)-82$ with yields in the range of $45-48 \%$ and an ee $>98 \%$, with recovery of unreacted starting material (-)-81 ( $>98 \%$ ee). Single enantiomers of $\mathbf{8 1}$ were incubated with $R$. erythropolis $A 4$ bacterial whole-cell preparations. The two hydrolysis steps occurred sequentially with nitrile hydratase $\left[-\mathrm{CN} \rightarrow-\mathrm{C}(=\mathrm{O}) \mathrm{NH}_{2}\right]$ and amidase $\left[-\mathrm{C}(=\mathrm{O}) \mathrm{NH}_{2} \rightarrow-\mathrm{COOH}\right]$ at the differing rates of 10 hours for (+)-81 and 24 hours for (-)-81, thus avoiding conventional chemical hydrolysis of nitriles in strongly acidic conditions and high temperature that result in degradation of the starting material. Optically pure cyclophellitols were accessed from these materials in three steps: esterification, reduction to the corresponding primary alcohol by LAH and epoxide formation by mCPBA.<smiles>N#C[C@H]1C=CC(O)[C@H](O)[C@H]1O</smiles>

R. miehei or

C. antarctica B lipase

$($ rac) $-\mathbf{8 1}$<smiles>N#CC1C=CC(O)[C](O)C1O</smiles>

(+)-81<smiles>N#CC1C=CC(O)C(O)[C@H]1O</smiles>

$(-)-81$<smiles>CC(=O)OC1C=CC(C#N)C(O)[C@H]1O</smiles>

(+)-82

98\%ee, $45-48 \%$ yield<smiles>NC(=O)C1C=CC(O)C(O)[C@H]1O</smiles>

(+)-83

R. erythropolis A4 Nitrile hydratase<smiles>NC(=O)C1C=CC(O)C(O)C1O</smiles>

$(-)-83$<smiles>N#CC1C=CC(O)C(O)C1O</smiles>

$(-)-81$

80-90\%ee<smiles>O=C(O)C1C=CC(O)[C](O)[C@H]1O</smiles>

Scheme 6. Use of lipase, nitrile hydratase and amidase in the enzyme resolution and biotransformation of cyanocyclitol precursors towards synthesis of cyclophellitol 2 and epicyclophellitol. ${ }^{149}$

\subsection{Inorganic Salts and Metal Trace Elements}

A limited number of studies have been reported on the action of inorganic salts and metal trace elements on $\alpha$-glycosidase action. ${ }^{150-156}$ The three main areas of investigation encompass 
a) the study of glucosidase and galactosidase inhibition in soils, b) the insulinomimetic activity of transition metal complexes, and c) the glycosidase inhibition by Pd complexes.

Soil borne glucosidase and galactosidase enzymes provide an important energy source for microorganisms. Eivazi et al. reported on the effects of soil treatments using inorganic salts and of trace elements on the activities of these enzymes. ${ }^{152}$ In general, the inorganic salts were stronger inhibitors of $\alpha$-glucosidase and $\alpha$-galactosidase activities (range 0 to $70 \%$ ) than the activities of their $\beta$-counterparts (range 0 to $44 \%$ ) [1 $\mathrm{g}$ of soil in the incubation medium made $8 \mathrm{mM}$ with respect to the inorganic salt]. The effect of trace elements on the activities of these enzymes varied considerably among the elements, enzymes and soils [ $1 \mathrm{~g}$ of soil in the incubation medium $(1 \mathrm{~mL})$ gave a $25 \mu \mathrm{M}$ concentration with respect to the trace element under evaluation]. The percentage inhibition of $\alpha$-glucosidase activity in Webster soil ranged from $11 \%$ with $\mathrm{Mo}^{4+}$ [as $\mathrm{H}_{2} \mathrm{MoO}_{4}$ ] to $66 \%$ with $\mathrm{Ag}^{+}$[as $\mathrm{Ag}_{2} \mathrm{SO}_{4}$ ] and in Luton soil ranged from $9 \%$ with $\mathrm{V}^{4+}$ [as $\mathrm{VOSO}_{4}$ ] to $66 \%$ with $\mathrm{Cd}^{2+}$ as $\mathrm{CdCl}_{2}$ ].

Yoshikawa and coworkers reported that $\mathrm{Zn}, \mathrm{Cu}$ and VO sulfate and picolinic acid (pa) complexes exhibit insulinomimetic activity. ${ }^{153,154}$ The modulation of $\alpha$-glucosidase inhibitory effect by metal ions and their complexes in the lowering of high blood-glucose levels in diabetic model animals has been reported. ${ }^{155}$ In vitro analysis revealed that divalent cations such as $\mathrm{Zn}^{2+}, \mathrm{Cu}^{2+} \mathrm{VO}^{2+}, \mathrm{Zn}(\mathrm{pa})_{2}$ and $\mathrm{Cu}(\mathrm{pa})_{2}$ were 4.7, 0.8, 201, 15 and $1.3 \mu \mathrm{M}$ inhibitors of $\alpha$-glucosidase activity, respectively (acarbose was used as a positive control). ${ }^{155}$ In vivo, the $\alpha$ glucosidase inhibition was studied in ddy-mice ${ }^{47}$ where it was found that the $\mathrm{Cu}^{2+}$ and its complexes produced the same effect as acarbose $(\sim 80 \mathrm{mg} / \mathrm{dL}$ blood glucose level vs $\sim 150$ $\mathrm{mg} / \mathrm{dL}$ for the control). These results suggested that $\mathrm{Cu}^{2+}$ and $\mathrm{Cu}(\mathrm{pa})_{2}$ inhibited the $\alpha-$ glucosidase action in the epithelium of the small intestine and reduced disaccharide digestion. Lineweaver-Burk plots show that $\mathrm{Cu}^{2+}$ and $\mathrm{Cu}(\mathrm{pa})_{2}$ act as a non-competitive inhibitors against $\alpha$-glucosidase (yeast).

Vasella and coworkers ${ }^{156}$ found that traces of Pd compounds, generated upon catalytic debenzylation in their synthesis of glycosidase inhibitors, proved to be themselves strong inhibitors. Palladium chloride $\left[\mathrm{PdCl}_{4}\right]^{2-}$ was determined to be a $40 \mu \mathrm{M}$ reversible inhibitor for the $\beta$-glucosidases (Clostridium saccharolyticum and sweet almonds) and a $19 \mu \mathrm{M}$ noncompetitive and revesible inhibitor of the $\alpha$-glucosidase (yeast). In addition, $\left[\mathrm{PdCl}_{4}\right]^{2-}$ inhibits two $\beta$-galactosidases (bovine liver and Escherichia coli) non-competitivly and reversibly with $\mathrm{K}_{\mathrm{i}} 36 \mu \mathrm{M}$ and $1.2 \mu \mathrm{M}$ respectively, and is a competitive and reversible inhibitor of both the $\alpha$ galactosidase (Aspergillus niger) with $\mathrm{K}_{\mathrm{i}} 5.8 \mu \mathrm{M}$, and the $\alpha$-galactosidase (coffee beans) with 
$\mathrm{K}_{\mathrm{i}} 4.8 \mu \mathrm{M}$. Thus particular care must be exercised when synthesising glycosidase inhibitors, especially in the removal of transition metal catalyst residue, e.g. from hydrogenation reactions, with flow chemistry approaches with embedded catalysts being potentially highly beneficial in this respect. ${ }^{157}$

\section{Conclusion}

Over 75 years since gluconolactone 1 was first discovered to inhibit glucosidases, research into new classes of glycosidase inhibitors continues to flourish. ${ }^{158,159}$ This is supported by a broader understanding of the tertiary structures of enzyme targets and the further uncovering of novel mechanisms in this family. ${ }^{98,160,161}$ Epoxides such as the natural product cyclophellitol and sulfonium ions like ones found naturally within the salicinol family were both discovered as synthetic classes of glycosidase inhibitor before they were identified in nature. ${ }^{84,146}$ The irreversible nature of epoxide inhibitors has recently allowed detection of proteins fused to a $\beta$ glucosidase in a cellular context. ${ }^{162}$ Intriguingly, epoxides have recently been postulated as intermediates in mannoside hydrolysis by glycosidases lacking a nucleophilic group near the anomeric site of cleavage. ${ }^{163-165}$ Research synergies between past and present work continue to drive this field forward. Particularly, the area of polycyclic aromatic natural products covered in our previous review ${ }^{38}$ has seen significant growth and will be the subject of a separate update.

\section{REFERENCES}

1. Jensen, H. H.; Lyngbye, L.; Jensen, A.; Bols, M. Stereoelectronic Substituent Effects in Polyhydroxylated Piperidines and Hexahydropyridazines. Chem. Eur. J. 2002, 8, 1218-1226.

2. Davies, G.; Henrissat, B. Structure and Mechanism of Glycosyl Hydrolases. Structure 1995, 3, 853-859.

3. Zechel, D. L.; Withers, S. G. Glycosidase Mechanisms: Anatomy of a Finely Tuned Catalyst. Acc. Chem. Res. 2000, 33, 11-18.

4. Wolfenden, R.; Lu, X.; Young, G. Spontaneous Hydrolysis of Glycosides. J. Am. Chem. Soc. 1998, 120, 6814-6815.

5. Vocadlo, D. J.; Davies, G. J. Mechanistic Insights into Glycosidase Chemistry. Curr. Opin. Chem. Biol. 2008; 12:539-555.

6. Bojarova, P.; Kren, V. Glycosidases: a Key to Tailored Carbohydrates. Trends Biotechnol. 2009, 27, 199-209.

7. Lairson, L. L.; Withers, S. G. Mechanistic Analogies amongst Carbohydrate Modifying Enzymes. Chem. Commun. 2004, 2243-2248.

8. Cobucci-Ponzano, B.; Perugino, G.; Rossi, M.: Moracci, M. Engineering the Stability and the Activity of a Glycoside Hydrolase. Protein Engineering, Design \& Selection 2011, 24, 21-26.

9. de Melo, E. B.; Gomes, A. d. S.; Carvalho, I. $\alpha$ - and $\beta$-Glucosidase Inhibitors: Chemical Structure and Biological Activity. Tetrahedron 2006, 62,10277-10302.

10. Lillelund, V. H.; Jensen, H. H.; Liang, X.; Bols, M. Recent Developments of Transition-State Analogue Glycosidase Inhibitors of Non-Natural Product Origin. Chem. Rev. 2002, 102, 515-553.

11. Vasella, A.; Davies, G. J.; Boehm, M. Glycosidase Mechanisms. Curr. Opin. Chem. Biol. 2002, 6, 619629.

12. Davies, G. J.; Ducros, V. M.-A.; Varrot, A.; Zechel, D. L. Mapping the Conformational Itinerary of $\beta$ Glycosidases by X-Ray Crystallography. Biochem. Soc. Trans. 2003, 31, 523-527. 
13. Jongkees, S. A. K.; Withers, S. G. Unusual Enzymatic Glycoside Cleavage Mechanisms. Acc. Chem. Res. 2014, 47, 226-235.

14. Davies, G. J.; Henrissat, B. Structural Enzymology of Carbohydrate-Active Enzymes: Implications for the Post-Genomic Era. Biochem. Soc. Trans. 2002, 30, 291-297.

15. Gloster, T. M.; Davies, G. J. Glycosidase inhibition: assessing mimicry of the transition state. Org. Biomol. Chem. 2010, 8, 305-320.

16. López, Ó.; Qing, F.-L.; Pedersen, C. M.; Bols, M. Enzyme inhibition by iminosugars: Analysis and insight into the glycosidase-iminosugar dependency of pH. Bioorg. Med. Chem. 2013, 21, 4755-4761.

17. Varrot, A.; Tarling, C. A.; Macdonald, J. M.; Stick, R. V.; Zechel, D. L.; Withers, S. G.; Davies, G. J. Direct Observation of the Protonation State of an Imino Sugar Glycosidase Inhibitor upon Binding. J. Am. Chem. Soc. 2003, 125, 7496-7497.

18. Varrot, A.; Macdonald, J. M.; Stick, R. V.; Pell, G.; Gilbert, H. J.; Davies, G. J. Distortion of a cellobioderived isofagomine highlights the potential conformational itinerary of inverting $\beta$-glucosidases. Chem.

Commun. 2003, 946-947.

19. Zechel, D. L.; Boraston, A. B.; Gloster, T. M.; Boraston, C. M.; Macdonald, J. M.; Tilbrook, M. G.; Stick, R. V.; Davies, G. J. Iminosugar Glycosidase Inhibitors: Structural and Thermodynamic Dissection of the Binding of Isofagomine and 1-Deoxynojirimycin to $\beta$-glucosidases. J. Am. Chem. Soc. 2003, 125, 14313-14323. 20. Gloster, T. M.; Macdonald, J. M.; Tarling, C. A.; Stick, R. V.; Davies, G. J. Structural, Thermodynamic, and Kinetic Analyses of Tetrahydrooxazine-derived Inhibitors Bound to $\beta$-Glucosidases. J. Biol. Chem. 2004, 279(47), 49236-49242.

21. Lee, J. K.; Bain, A. D.; Berti, P. J. Probing the Transition States of Four Glucoside Hydrolyses with ${ }^{13} \mathrm{C}$ Kinetic Isotope Effects Measured at Natural Abundance by NMR Spectroscopy. J. Am. Chem. Soc. 2004, 126, 3769-3776.

22. Risseauw, M. D. P.; Overhand, M.; Fleet, G. W. J.; Simone, M. I. A Compendium of Cyclic Sugar Amino Acids and their Carbocyclic and Heterocyclic Nitrogen Analogues. Amino Acids 2013, 45, 613-689.

23. Risseauw, M. D. P.; Overhand, M.; Fleet, G. W. J.; Simone, M. I. A Compendium of Sugar Amino Acids (SAA): Scaffolds, Peptide- and Glyco-Mimetics. Tetrahedron: Asymm. 2007, 18, 2001-2010.

24. Stuetz, A. E. Iminosugars as Glycosidase Inhibitors: Nojirimycin and Beyond. Wiley-VCH; 1999.

25. Kim, I. S.; Jung, Y. H. Recent Advances in the Total Synthesis of Indolizidine Iminosugars. Heterocycles 2011, 83, 2489-2507.

26. Wrodnigg, T. M. From Lianas to Glycobiology Tools: Twenty-Five Years of 2,5-Dideoxy-2,5-imino-Dmannitol. Monatsch. fuer Chemie 2002, 133, 393-426.

27. Xavier, N. M.; Rauter, A. P.; Queneau, Y. Carbohydrate-Based Lactones: Synthesis and Applications.

Topics Curr. Chem. 2010, 295, 19-62.

28. Cipolla, L.; Ferla, B. L.; Airoldi, C.; Zona, C.; Orsato, A.; Shaikh, N.; Russo, L.; Nicotra, F. Carbohydrate Mimetics and Scaffolds: Sweet Spots in Medicinal Chemistry. Future Med. Chem. 2010, $2,587-$ 599.

29. Asano, N. Alkaloidal Sugar Mimetics: Biological Activities and Therapeutic Applications. J. Enzyme Inhib. 2000, 15, 215-234.

30. Glawar, A. F. G.; Best, D.; Ayers, B.; Miyauchi, S.; Nakagawa, S.; Aguilar-Moncayo, M.; Fernández, J. M. G.; Mellet, C. O.; Crabtree, E. V.; Butters, T. D.; Wilson, F. X.; Kato, A.; Fleet, G. W. J. Scalable Syntheses of both Enantiomers of DNJNAc and DGJNAc from Glucuronolactone; Effect of N-Alkylation on Hexosaminidase Inhibition. Chem. Eur. J. 2012, 18, 9341-9359.

31. de Cruz, F. P.; Newberry, S.; Jenkinson, S. F.; Wormald, M. R.; Butters, T. D.; Alonzi, D. S.; Nakagawa, S.; Becq, F.; Norez, C.; Nash, R. J.; Kato, A.; Fleet, G. W. J. 4-C-Methyl-DAB and 4-C-Me-LAB enantiomeric alkyl branched pyrrolidine iminosugars - are specific and potent a-glucosidase inhibitors; acetone as the sole protecting group. Tetrahedron Lett. 2011, 52, 219-223.

32. Jenkinson, S. F.; Fleet, G. W. J.; Nash, R. J.; Koike, Y.; Adachi, I.; Yoshihara, A.; Morimoto, K.; Izumori, K.; Kato, A. Looking-glass Synergistic Pharmacological Chaperones: DGJ and L-DGJ from the Enantiomers of Tagatose. Organic Lett. 2011;13:4064-4067.

33. Dragutan, I.; Dragutan, V.; Demonceau, A. Targeted Drugs by Olefin Metathesis: Piperidine-based Iminosugars. RSC Advances 2012, 2, 719-736.

34. Cipolla, L.; Ferla, B. L.; Gregori, M. Combinatorial Approaches to Iminosugars as Glycosidase and Glycosyltransferase Inhibitors. Combi. Chem. High Throughput Screen. 2006, 9, 571-582.

35. Salgueiro, D. A. L.; Sousa, C. E. A.; Fortes, A. G.; Alves, M. J. Diels-Alder Cycloaddition in the Synthesis of 1-Azafagomine, Analogs, and Derivatives as Glycosidase Inhibitors. Mini-Rev. Med. Chem. 2012, $12,1465-1476$.

36. Afarinkia, K.; Bahar, A. Recent Advances in the Chemistry of Azapyranose Sugars. Tetrahedron:

Asymm. 2005, 16, 1239-1287.

37. Compain P.; Martin, O. R. Imino Sugars: From Synthesis to Therapeutic Applications: Wiley; 2007.

38. Houston, T. A.; Blanchfield, J. T. Back to (non)-Basics: Recent Developments in Neutral and ChargeBalanced Glycosidase Inhibitors. Mini-Rev. Med. Chem. 2003, 3, 669-678. 
39. von Itzstein, M. The war against influenza: discovery and development of sialodase inhibitors. Nature Rev. Drug. Disc. 2007, 6, 967-974.

40. Nakatsugawa, S.; Okuda, T.; Muramoto, H. Inhibitory effect of ND2001 on spontaneous multiple metastases of NC 65 tumors derived from human renalcancer cells intradermally transplanted into nude mice. Anti-Cancer Drugs 1999, 10, 229-233.

41. Kuramitsu, Y.; Hamada, J.; Tsuruoka, T.; Morikawa, K.; Kobayashi, H.; Hosokawa, M. A New Antimetastatic Drug, ND-2001, inhibits Lung Metastases in Rat Hepatoma Cells by Suppressing Haptotaxis of Tumor Cells toward Laminin. Anti-Cancer Drugs 1998, 9, 88-93.

42. Willems, L. I.; Beenakker, T. J. M.; Murray, B.; Scheij, S.; Kallemeijn, W. W.; Boot, R. G.; Verhoek, M.; Donker-Koopman, W. E.; Ferraz, M. J.; v. Rijssel, E. R.; Florea, B. I.; Codée, J. D. C.; van der Marel, G. A.; Aerts, J. M. F. G.; Overkleeft, H. S. Potent and Selective Activity-Based Probes for GH27 Human Retaining $\alpha-$ Galactosidases. J. Am. Chem. Soc. 2014, 136, 11622-11625.

43. Wu, H. J.; Ho, C. W.; Ko, T. P.; Popat, S. D.; Lin, C. H.; Wang, A. H. J. Structural Basis of $\alpha-$ Fucosidase Inhibition by Iminocyclitols with Ki Values in the Micro- to Picomolar Range. Angew. Chem. Intl. Ed. 2010, 49, 337-340.

44. Bulmer, M. S.; Blachelet, I.; Raman, R.; Rosengaus, R. B.; Sasisekharan, R. Targeting an antimicrobial effector function in insect immunity as a pest control strategy. Proc. Nat. Acad. Sci. USA 2009, 131, 1265212657.

45. Wicki, J.; Williams, S. J.; Withers, S. G. Transition-State Mimicry by Glycosidase Inhibitors: A Critical Kinetic Analysis. J. Am. Chem. Soc. 2007, 129, 4530-4531.

46. Terinek, M; Vasella, A. Synthesis and Evaluation of Two Mannosamine-derived Lactone-type Inhibitors of Snail $\beta$-Mannosidase. Tetrahedron: Asymm. 2005, 16, 449-469.

47. Yamazaki, T. Kishimoto, K.; Ezaki, O. The ddY mouse: a model of postprandial hypertriglyceridemia in response to dietary fat. J. Lipid Res. 2012, 53, 2024-2037.

48. $\quad$ McGovern, S. L.; Caselli, E.; Grigorieff, N.; Shoichet, B. K. A Common Mechanism Underlying Promiscuous Inhibitors from Virtual and High-Throughput Screening. J. Med. Chem. 2002, 45, 1712-1722.

49. Sivasothy, Y.; Lo, K. Y.; Kok Hoong, L.; Litaudon, M.; Awang, K. A potent alpha-glucosidase inhibitor from Myristica cinnamomea King. Phytochemistry 2016, 122, 265-269.

50. Yu, C.; Crispin, M.; Sonnen, A. F.-P.; Harvey, D. J.; Chang, V. T.; Evans, E. J.; Scanlan, C. N.; Stuart, D. I.; Gilbert, R. J. C.; Davis, S. J. Use of the $\alpha$-mannosidase I inhibitor kifunensine allows the crystallization of apo CTLA-4 homodimer produced in long-term cultures of Chinese hamster ovary cells. Acta Cryst. Section F 2011, 67, 785-789.

51. Hering, K. W.; Karaveg, K.; Moremen, K. W.; Pearson, W. H. A Practical Synthesis of Kifunensine Analogues as Inhibitors of Endoplasmic Reticulum $\alpha$-Mannosidase I. J. Org. Chem. 2005, 70, 9892-9904.

52. Csuk, R.; Prell, E. Difluorotetrahydropyridothiazinone: A Selective $\beta$-Galactosidase Inhibitor. Arch Pharm. Chem. Life Sci. 2010, 10, 577-582.

53. Cardona, F.; Moreno, G.; Guarna, F.; Vogel, P.; Schuetz, C.; Merino, P.; Goti, A. New Concise Total Synthesis of (+)-Lentiginosine and Some Structural Analogues. J. Org. Chem. 2005, 70, 6552-6555.

54. Kawatkar, S. P.; Kuntz, D. A.; Woods, R. J.; Rose, D. R.; Boons, G.-J. Structural Basis of the Inhibition of Golgi $\alpha$-Mannosidase II by Mannostatin A and the Role of the Thiomethyl Moiety in Ligand-Protein Interactions. J. Am. Chem. Soc. 2006, 128, 8310-8319.

55. García-Moreno, M. I.; Rodríguez-Lucena, D.; C. O. Mellet, J. M. G. Fernández. Pseudoamide-Type Pyrrolidine and Pyrrolizidine Glycomimetics and Their Inhibitory Activities against Glycosidases. J. Org. Chem. 2004, 69, 3578-3581.

56. Pandey, G.; Dumbre, S. G.; Khan, M. I.; Shabab, M.; Puranik, V. G. A $\beta$-Lactam-azasugar Hybrid as a Competitive Potent Galactosidase Inhibitor. Tetrahedron Lett. 2006, 47, 7923-7926.

57. $\quad$ Sridhar, P. R.; Seshadri, K.; Reddy, G. M. Stereoselective synthesis of sugar fused $\beta$-disubstituted $\gamma-$ butyro-lactones: C-spiro-glycosides from 1,2-cyclopropanecarboxylated sugars. Chem. Commun. 2012, 48, 756758.

58. Goyard, D.; Telligmann, S. M.; Goux-Henry, C.; Boysen, M. M. K.; Framery, E.; Gueyrard, D.; Vidal, S. Carbohydrate-Based Spiro Bis(isoxazolines): Synthesis and Evaluation in Asymmetric Catalysis. Tetrahedron Lett. 2010, 51, 374-377.

59. Soengas, R. G. A Straightforward Route to Novel $\alpha, \alpha$-Disubstituted Tetrahydrofuran $\beta$-Amino Acids and Spirodiketopiperazines from Sugar Lactones. Synlett 2010, (17), 2549-2552.

60. Maza, S.; Lopez, O.; Martos, S.; Maya, I.; Fernandez-Bolanos, J. G. Synthesis of the First SeleniumContaining Acyclic Nucleosides and Anomeric Spironucleosides from Carbohydrate Precursors. Eur. J. Org. Chem. 2009, 5239-5246.

61. Fuentes, J.; Salameh, B. A. B.; Pradera, M. A.; d. Cordoba, F. J. F.; Gasch, C. Stereocontrolled Synthesis of Thiohydantoin Spironucleosides from Sugar Spiroacetals. Tetrahedron 2006, 62, 97-111. 62. Kancharla, P. K.; Vankar, Y. D. Chemistry of 2-Nitroglycals: A One-Pot Three-Component Stereoselective Approach toward 2-C-Branched O-Galactosides. J. Org. Chem. 2010, 75, 8457-8464. 
63. Babu, B. R.; Keinicke, L.; Petersen, M.; Nielsen, C.; Wengel, J. 2'-Spiro Ribo- and Arabino-nucleosides: Synthesis, Molecular Modelling and Incorporation into Oligodeoxynucleotides. Org. Biomol. Chem. 2003, 1, 3514-3526.

64. Gasch, C.; Merino-Montiel, P.; Lopez, O.; Fernandez-Bolanos, J. G.; Fuentes, J. Spiranic D-Glucoconfigured N-Substituted Thiohydantoins as Potential Enzymatic Inhibitors. Tetrahedron 2010, 66, 9964-9973. 65. Suryawanshi, S. B.; Dushing, M. P.; Gonnade, R. G.; Ramana, C. V. The Isochroman- and 1,3Dihydroisobenzofuran-annulation on Carbohydrate Templates via 2+2+2-Cyclotrimerization and Synthesis of some Tricyclic Nucleosides. Tetrahedron 2010, 66, 6085-6096.

66. Richter, S. N.; Menegazzo, I.; Nadai, M.; Moro, S.; Palumbo, M. Reactivity of Clerocidin Towards Adenine: Implications for Base-modulated DNA Damage. Org. Biomol. Chem. 2009, 7, 976-985.

67. Gasch, C.; Illangua, J. M.; Merino-Montiel, P.; Fuentes, J. Stereocontrolled Synthesis of $(5+5),(5+6)$ and (6+6) 3-Spiropseudonucleosides. Tetrahedron 2009, 65, 4149-4155.

68. Maurya, S. K.; Hotha, S. Synthesis of Spiroannulated Dihydroisobenzofuranylated Monosaccharides. Tetrahedron Lett. 2006, 47, 3307-3310.

69. Nhien, A. N. V.; Dominguez, L.; Tomassi, C.; Torres, M. R.; Len, C.; Postel, D.; Marco-Contelles, J. Synthesis and Transformations of 1,2-O-Isopropylidene- $\alpha$-D-erythro (and $\alpha$-D-ribo)furanose-3-spiro-3'-(4'amino-5 H-2',3'-dihydroisothiazole-1',1'-dioxide) Derivatives. Tetrahedron 2004, 60, 4709-4727.

70. Nguyen, A.; Villa, P.; Ronco, G.; Postel, D. Spirohydantoins from D-Ribose as New Potent Enzymatic Inhibitors. J. Pharm. Pharmacol. 2001, 53, 939-943.

71. Shibata, K.; Hiruma, K.; Kanie, O.; Wong, C. H. Synthesis of 1,1-Linked Galactosyl Mannosides Carrying a Thiazine Ring as Mimetics of Sialyl Lewis X Antigen: Investigation of the Effect of Carboxyl Group Orientation on P-Selectin Inhibition. J. Org. Chem. 2000, 65, 2393-2398.

72. Postel, D.; Nhien, A. N. V.; Villa P.; Ronco, G. Novel Spirohydantoins of D-Allose and D-Ribose derived from Glyco- $\alpha$-aminonitriles. Tetrahedron Lett. 2001, 42, 1499-1502.

73. Maity, J. K.; Ghosh, R.; Drew, M. G. B.; Achari, B.; Mandal, S. B. Introduction of Vinyl and Hydroxymethyl Functionalities at C-4 of Glucose-derived Substrates: Synthesis of Spirocyclic, Bicyclic, and Tricyclic Nucleosides. J. Org. Chem. 2008, 73, 4305-4308.

74. Roy, A.; Achari, B.; Mandal, S. B. An Easy Access to Spiroannulated Glyco-oxetane, -thietane and azetane Rings: Synthesis of Spironucleosides. Tetrahedron Lett. 2006, 47, 3875-3879.

75. Bichard, C. J. F.; Mitchell, E. P.; Wormald, M. R.; Watson, K. A.; Johnson, L. N.; Zographos, S. E.; Koutra, D. D.; Oikonomakos, N. G.; Fleet, G. W. J. Potent Inhibition of Glycogen-Phosphorylase by a Spirohyantoin of Glucopyranose - First Pyranose Analogs of Hydantocidin. Tetrahedron Lett. 1995, 36, 21452148.

76. Pal, A. P. J.; Vankar, Y. D. Azidation of Anomeric Nitro Sugars: Application in the Synthesis of Spiroaminals as Glycosidase Inhibitors. Tetrahedron Lett. 2010, 51, 2519-2524.

77. Merino-Montiel, P.; Lopez, O.; Alvarez, E.; Fernandez-Bolanos, J. G. Synthesis of Conformationallyconstrained Thio(seleno)hydantoins and $\alpha$-Triazolyl Lactones from D-Arabinose as Potential Glycosidase Inhibitors. Tetrahedron 2012, 68, 4888-4898.

78. Merino-Montiel, P.; Lopez, O.; Fernandez-Bolanos, J. G. Unprecedented Spiro-annelated Sugar Isoureas, Guanidines and Amidines as New Families of Glycosidase Inhibitors. RSC Advances 2012, 2, 1132611335.

79. Xie, W.; Tanabe, G.; Xu, J.; Wu, X.; Morikawa, T.; Yoshikawa, M.; Muraoka, O. Research Progress of Synthesis and Structure-activity Relationship Studies on Sulfonium-type $\alpha$-glucosidase Inhibitors Isolated from Salacia Genus Plants. Mini-Rev. Org. Chem. 2013, 10, 141-159.

80. Mohan, S.; Eskandari, R.; Pinto, B. M. Naturally Occurring Sulfonium-Ion Glucosidase Inhibitors and Their Derivatives: A Promising Class of Potential Antidiabetic Agents. Acc. Chem. Res. 2014, 47, 211-225.

81. Sankar, M.; Pinto, B. M. Zwitterionic glycosidase inhibitors: salacinol and related analogues. Carbohydr. Res. 2007, 342, 1551-1580.

82. Witczak, Z. J.; Culhane, J. M. Thiosugars: New Perspectives regarding Availability and Potential Biochemical and Medicinal Applications. Appl. Microbiol. Biotechnol. 2005, 69, 237-244.

83. Xie, W.-J.; Tanabe, G.; Tsutsui, N.; Wu, X.-M.; Muraoka, O. Total Synthesis of Neokotalanol, a Potent $\alpha$-Glucosidase Inhibitor isolated from Salacia reticulata. Chinese J. Nat. Med. 2013, 11, 676-683.

84. For a synthetic sulfonium species that was the first compound of this type to show glycosidase inhibiton, see: Siriwardena, A. H., Chiaroni, A., Riche, C., El-Daher, S., Winchester, B., Grierson, D. S. Chem. Commun., 1992, 1531.

85. Xie, W.-J.; Tanabe, G.; Xu, J. Y.; Wu, X.-M.; Morikawa, T.; Yoshikawa, M.; Muraoka, O. Research Progress of Synthesis and Structure-activity Relationship Studies on Sulfonium-type $\alpha$-glucosidase Inhibitors Isolated from Salacia Genus Plants. Mini-Rev. Org. Chem. 2013, 10, 141-159.

86. Yuasa, H.; Izumi, M.; Hashimoto, H. Thiasugars: Potential Glycosidase Inhibitors. Curr. Top. Med. Chem. 2009, 9, 76-86.

87. Hadwiger, P.; Stütz A. E.; Wrodnigg, T. M. Sulfur Containing Glycomimetics in Glycoscience: Chemistry and Chemical Biology I, B. Fraser-Reid, Ed. Springer-Verlag: New York, 2011; pp. 2264-2275. 
88. Mohan, S.; Pinto, B. M. Sulfonium-ion Glycosidase Inhibitors Isolated from Salacia Species used in Traditional Medicine, and Related Compounds. Coll. Czech. Chem. Commun. 2009, 74, 1117-1136.

89. Mohan, S.; Eskandari, R.; Pinto, B. M. Naturally Occurring Sulfonium-Ion Glucosidase Inhibitors and Their Derivatives: A Promising Class of Potential Antidiabetic Agents. Acc. Chem. Res. 2014, 47, 211-225.

90. Mohan, S.; Pinto, B. M. Towards the Elusive Structure of Kotalanol, a Naturally Occurring Glucosidase Inhibitor. Nat. Prod. Rep. 2010, 27, 481-488.

91. Gao, H.; Huang, Y.-N.; Gao, B.; Li, P.; Inagaki, C.; Kawabata, J. Inhibitory Effect on $\alpha$-glucosidase by Adhatoda vasica Nees. Food Chem. 2008, 108, 965-972.

92. Li, Y.; Huang, T. H.-W.; Yamahara, J. Salacia root, a unique Ayurvedic medicine, meets multiple targets in diabetes and obesity. Life Sci. 2008, 82, 1045-1049.

93. Minami, Y.; Kuriyama, C.; Ikeda, K.; Kato, A.; Takebayashi, K.; Adachi, I.; Fleet, G. W. J.; Kettawan, A.; Okamotoe, T.; Asano, N. Effect of five-membered sugar mimics on mammalian glycogen-degrading enzymes (glycogen phosphorylase [GP] and amylo-1,6-glucosidase) and various glucosidases. Bioorg. Med. Chem. 2008, 16, 2734-2740.

94. Muraoka, O.; Xie, W. J.; Tanabe, G.; Amer, M. F. A.; Minematsu, T.; Yoshikawa, M. On the Structure of the Bioactive Constituent from Ayurvedic Medicine Salacia reticulata: Revision of the Literature. Tetrahedron Lett. 2008, 49, 7315-7317.

95. Oe, H.; Ozaki, S. Hypoglycemic Effect of 13-Membered Ring Thiocyclitol, a Novel $\alpha$-Glucosidase Inhibitor from Kothala-himbutu (Salacia reticulata). Biosci. Biotechnol. Biochem. 2008, 72, 1962-1964.

96. Piparo, E. L.; Scheib, H.; Frei, N.; Williamson, G.; Grigorov, M.; C. J. Chou, C. J. Flavonoids for Controlling Starch Digestion: Structural Requirements for Inhibiting Human $\alpha$-Amylase. J. Med. Chem. 2008, $51,3555-3561$.

97. Subramanian, R.; Asmawi, M. Z.; Sadikun, A. In vitro $\alpha$-glucosidase and $\alpha$-amylase enzyme inhibitory effects of Andrographis paniculata extract and andrographolide. Acta Biochim. Polonica 2008, 55, 391-398.

98. Tailford, L. E.; Offen, W. A.; Smith, N. L.; Dumon, C.; Morland, C.; Gratien, J.; Heck, M.-P.; Stick, R. V.; Blériot, Y.; Vasella, A.; Gilbert, H. J.; Davies, G. J. Structural and Biochemical Evidence for a Boat-like Transition State in $\beta$-Mannosidases. Nature Chem. Biol. 2008, 4, 306-312.

99. Yoshikawa, M.; Murakami, T.; Shimada, H.; Matsuda, H.; Yamahara, J.; Tanabe G.; Muraoka, O. Salacinol, Potent antidiabetic Principle with Unique Thiosugar Sulfonium Sulfate Structure from the Ayurvedic Traditional Medicine Salacia reticulata in Sri Lanka and India. Tetrahedron Lett. 1997, 38, 8367-8370.

100. Yoshikawa, M.; Morikawa, T.; Matsuda, H.; Tanabe, G.; Muraoka, O. Absolute Stereostructure of Potent $\alpha$-Glucosidase Inhibitor, Salacinol, with Unique Thiosugar Sulfonium Sulfate Inner Salt Structure from Salacia reticulata. Bioorg. Med. Chem. 2002, 10, 1547-1554.

101. Tanabe, G.; Yoshikai, K.; Hatanaka, T.; Yamamoto, M.; Shao, Y.; Minematsu, T.; Muraoka, O.; Wang, T.; Matsuda, H.; Yoshikawa, M. Biological Evaluation of De-O-sulfonated Analogs of Salacinol, the Role of Sulfate Anion in the Side Chain on the $\alpha$-Glucosidase Inhibitory Activity. Bioorg. Med. Chem. 2007, 15, 39263937.

102. Goss, P. E.; Baker, M. A.; Carver, J. P.; Dennis, J. W. Inhibitors of Carbohydrate Processing: A New Class of Anticancer Agents. Clin. Cancer Res. 1995, 1, 935-944.

103. Van den Broek, L. A. G. M. Azasugars: Chemistry and their Biological Activity as Potential Anti-HIV Drugs. In Carbohydrates in Drug Design Z. J. Witczak and K. A. Nieforth, Eds. Marcel Dekker: New York; 1997, pp. 471-493.

104. Cox, T.; Lachmann, R.; Hollak, C.; Aerts, J.; Weely, S. v.; Hrebícek, M.; Platt, F.; Butters, T.; Dwek, R.; Moyses, C.; Gow, I.; Elstein, D.; Zimran, A. Novel oral treatment of Gaucher's disease with Nbutyldeoxynojirimycin (OGT 918) to decrease substrate biosynthesis. Lancet 2000, 355,1481-1485.

105. Yoshikawa, M.; Xu, F.; Nakamura, S.; Wang, T.; Matsuda, H.; Tanabe, G.; Muraoka, O. Salaprionol and Ponkoranol with Thiosugar Sulfonium Sulfate Structure from Salacia prinoides and $\alpha$-Glucosidase Inhibitory Activity of Ponkoranol and Kotalanol Desulfate. Heterocycles 2008, 75, 1397-1405.

106. Koshland, D. E. Stereochemistry and the Mechanism of Enzymatic Reactions. Biol. Rev. 1953, 28, 416-

436.

107. McCarter, J. D.; Withers, S. G. Mechanisms of Enzymatic Glycoside Hydrolysis. Curr. Opin. Struct. Biol. 1994, 4, 885-892.

108. Dwek, R. A. Glycobiology: Toward Understanding the Function of Sugars. Chem. Rev. 1996, 96, 683-

109. Yuasa, H.; Izumi, M.; Hashimoto, H. Thiasugars: Potential Glycosidase Inhibitor. J. Synth. Org. Chem. Jpn. 2002, 60, 774-782.

110. Sankar, M.; Pinto, B. M. Zwitterionic glycosidase inhibitors: salacinol and related analogues.

Carbohydr. Res. 2007, 342, 1551-1580. 
111. Xie, W.; Tanabe, G.; Akaki, J.; Morikawa, T.; Ninomiya, K.; Minematsu, T.; Yoshikawa, M.; Wu, X.; Muraoka, O. Isolation, Structure Identification and SAR Studies on Thiosugar Sulfonium Salts, Neosalaprinol and Neoponkoranol, as Potent $\alpha$-Glucosidase Inhibitors. Bioorg. Med. Chem. 2011, 19, 2015-2022.

112. Tanabe, G.; Xie, W. J.; Ogawa, A.; Cao, C. N.; Minematsu, T.; Yoshikawa, M.; Muraoka, O. Facile synthesis of de-O-sulfated salacinols: Revision of the structure of neosalacinol, a potent alpha-glucosidase inhibitor. Bioorg. Med. Chem. Lett. 2009, 19, 2195-2198.

113. Tanabe, G.; Otani, T.; Cong, W.; Minematsu, T.; Ninomiya, K.; Yoshikawa, M.; Muraoka, O. Biological Evaluation of 3'-O-Alkylated Analogs of Salacinol, the Role of Hydrophobic Alkyl Group at 3'-Position in the Side Chain on the $\alpha$-Glucosidase Inhibitory Activity. Bioorg. Med. Chem. Lett. 2011, 21, 3159-3162.

114. Eskandari, R.; Jones, K.; Rose, D. R.; Pinto, B. M. Selectivity of 3'-O-methylponkoranol for inhibition of $\mathrm{N}$ - and C-terminal maltase glucoamylase and sucrase isomaltase, potential therapeutics for digestive disorders or their sequelae. Bioorg. Med. Chem. Lett. 2011, 21, 6491-6494.

115. Muraoka, O.; Morikawa, T.; Miyake, S.; Akaki, J.; Ninomiya, K.; Pongpiriyadacha, Y.; Yoshikawa, M. Quantitative analysis of neosalacinol and neokotalanol, another two potent $\alpha$-glucosidase inhibitors from Salacia species, by LC-MS with ion pair chromatography. J. Nat. Med. 2011, 65,142-148.

116. Ozaki, S.; Oe, H.; Kitamura, S. $\alpha$-Glucosidase Inhibitor from Kothala-himbutu (Salacia reticulata WIGHT). J. Nat. Prod. 2008, 71, 981-984.

117. Tanabe, G.; Matsuoka, K.; Yoshinaga, M.; Xie, W.; Tsutsui, N.; Amer, M. F. A.; Nakamura, S.; Nakanishi, I.; Wub, X.; Yoshikawa, M.; Muraoka, O. Role of the Side Chain Stereochemistry in the $\alpha$ Glucosidase Inhibitory Activity of Kotalanol, a Potent Natural $\alpha$-Glucosidase Inhibitor. Part 2. Bioorg. Med. Chem. 2012, 20, 6321-6334.

118. Liu, H.; Sim, L.; Rose, D. R.; Pinto, B. M. A New Class of Glucosidase Inhibitor: Analogues of the Naturally Occurring Glucosidase Inhibitor Salacinol with Different Ring Heteroatom Substituents and Acyclic Chain Extension. J. Org. Chem. 2006, 71, 3007-3013.

119. Yin, Z.; Zhang, W.; Feng, F.; Zhang, Y.; Kang, W. $\alpha$-Glucosidase inhibitors isolated from medicinal plants. Food Sci. Human Wellness 2014, 3, 136-174.

120. Muraoka, O.; Yoshikai, K.; Takahashi, H.; Minematsu, T.; Lu, G.; Tanabe, G.; Wang, T.; Matsuda, H.; Yoshikawa, M. Synthesis and Biological Evaluation of Deoxy Salacinols, the Role of Polar Substituents in the Side Chain on the $\alpha$-Glucosidase Inhibitory Activity. Bioorg. Med. Chem. 2006, 14, 500-509.

121. Gu, G.; Lui, H.; Pinto, B. M. Facile synthesis of sulfonium ion derivatives of 1,5-anhydro-5-thio-Lfucitol as potential $\alpha$-L-fucosidase inhibitors. Carbohydr. Res. 2006, 341, 2478-2486.

122. Wolf, B. W.; Weisbrode, S. E. Safety Evaluation of an Extract from Salacia oblonga. Food Chem. Toxicol. 2003, 41, 867-874.

123. Matsuda, H.; Murakami, T.; Yashiro, K.; Yamahara, J.; Yoshikawa, M. Antidiabetic Principles of Natural Medicines. IV. Aldose Reductase and $\alpha$-Glucosidase Inhibitors from the Roots of Salacia oblonga Wall. (Celastraceae): Structure of a New Friedelane-type Triterpene, Kotalagenin 16-Acetate. Chem. Pharm. Bull. 1999, 47, 1725-1729.

124. Stubbs, K. A.; Vocadlo, D. J. Affinity-Based Proteomics Probes; Tools for Studying CarbohydrateProcessing Enzymes. Aust. J. Chem. 2009, 62, 521-527.

125. Rempel, B. P.; Withers, S. G. Covalent inhibitors of glycosidases and their applications in biochemistry and biology. Glycobiology 2008, 18, 570-586.

126. Atsumi, S.; Iinuma, H.; Nosaka C.; Umezawa, K. Biological Activities of Cyclophellitol. J. Antibiotics 1990, 43, 1579-1585.

127. Atsumi, S.; Imezawa, K.; Iinuma, H.; Naganawa, H.; Nakamura, H.; Iitaka Y.; Takeuchi, T. Production, Isolation and Structure Determination of a Novel $\beta$-Glucosidase Inhibitor, Cyclophellitol, from Phellinus sp. $J$. Antibiotics 1990, 43, 49-53.

128. Gloster, T. M.; Madsen, R.; Davies, G. J. Structural Basis for Cyclophellitol Inhibition of a $\beta$ Glucosidase. Org. Biomol. Chem. 2006, 5, 444-446.

129. Schlessinger, R. H.; Bergstrom, C. P. Enantioselective Synthesis of (+)-Cyclophellitol. J. Org. Chem. 1995, 60,16-17.

130. Trost, B. M.; Patterson D. E.; Hembre, E. J. AAA in KAT/DYKAT Processes: First- and SecondGeneration Asymmetric Syntheses of (+)- and (-)-Cyclophellitol. Chem. Eur. J. 2001, 7, 3768-3775.

131. McDevitt, R. E.; Fraser-Reid, B. A Divergent Route for a Total Synthesis of Cyclophellitol and Epicyclophellitol from a [2.2.2] Oxabicyclic Glycoside Prepared from D-Glucal. J. Org. Chem. 1994, 59, 32503252.

132. Sato, K.; Bokura, M.; Moriyama, H.; Igarashi, T. Total Synthesis of a Novel $\beta$-Glucosidase Inhibitor, Cyclophellitol Starting from D-Glucose. Chem. Lett. 1994, 23, 37-40.

133. Jung, M. E.; Choe, S. W. T. Total Synthesis of Cyclophellitol and (1R,2S)-Cyclophellitol from DMannose. J. Org. Chem. 1995, 60, 3280-3281. 
134. Takahashi, H.; Iimori, T.; Ikegami, S. An Efficient Synthesis of Cyclophellitol Utilizing Unusual Regioselectivity of Oxirane Ring Opening with Mes2BCH2Li. Tetrahedron Lett. 1998, 39, 6939-6942.

135. Akiyama, T.; Shima, H.; Ohnari, M.; Okazaki T.; Ozaki, S. Synthesis of (-)-Conduritol F, (+)-

Conduritol B, Cyclophellitol from L-Quebrachitol. Bull. Chem. Soc. Jpn. 1993, 66, 3760-3767.

136. Shing, T. K. M.; Tai, V. W. F. Facile Syntheses of Cyclophellitol and its (1R,6S)-, (1R,2S,6S)-, (2S)-

Diastereoisomers from (-)-Quinic Acid. Chem. Commun. 1993, 995-996.

137. Ishikawa, T.; Shimizu, Y.; Kudoh, T.; Saito, S. Conversion of D-Glucose to Cyclitol with

Hydroxymethyl Substituent via Intramolecular Silyl Nitronate Cycloaddition Reaction: Application to Total

Synthesis of (+)-Cyclophellitol. Org. Lett. 2003, 5, 3879-3882.

138. Hansen, F. G.; Bundgaard, E.; Madsen, R. A Short Synthesis of (+)-Cyclophellitol. J. Org. Chem. 2005, 70,10139-10142.

139. Nitta, M.; Yi, A.; Kobayashi, T. Nonacarbonyldiiron-, Pentacarbonyliron-, or

Hexacarbonylmolybdenum-induced Reactions of 4,5-Polymethylene-substituted 2-Isoxazolines. Bull. Chem. Soc. Jpn. 1985, 58, 991-994.

140. Kireev, A. S.; Breithaupt, A. T.; Collins, W.; Nadein, O. N.; Kornienko, A. Enantiodivergent Formal Synthesis of (+)- and (-)-Cyclophellitol from D-Xylose Based on the Latent Symmetry Concept. J. Org. Chem. 2005, 70, 742-745.

141. Popsavin, V.; Krstic, I.; Popsavin, M.; Zelenovic, B. S., Kojic, V.; Bogdanovic, G. Enantiodivergent synthesis of muricatacin related lactones from D-xylose based on the latent symmetry concept: preparation of two novel cytotoxic (D)- and (L)-muricatacin 7-oxa analogs. Tetrahedron 2006, 62, 11044-11053.

142. Hudlicky, T. Design Constraints in Practical Syntheses of Complex Molecules: Current Status, Case Studies with Carbohydrates and Alkaloids, and Future Perspectives. Chem. Rev. 1996, 96, 3-30.

143. Ball, M.; Gaunt, M. J.; Hook, D. F.; Jessiman, A. S.; Kawahara, S.; Orsini, P.; Scolaro, A.; Talbot, A. C.; Tanner, H. R.; Yamanoi, S.; Ley, S. V. Total Synthesis of Spongistatin 1: A Synthetic Strategy Exploiting Its Latent Pseudo-Symmetry. Angew Chem. Intl. Ed. 2005, 44, 5433-5438.

144. Serrano, P.; Egido-Gabás, M.; Llebaria, A.; Delgado, A. An Unexpected Access to 5-epi-Cyclophellitol: a New Cyclitol Member. Tetrahedron: Asymm. 2007, 18, 1971-1974.

145. Premkumar, L.; Sawkar, A. R.; Boldin-Adamsky, S.; Toker, L.; Silman, I.; Kelly, J. W.; Futerman, A. H.; Sussman, J. L. X-ray Structure of Human Acid--Glucosidase Covalently Bound to Conduritol-B-Epoxide. $J$. Biol. Chem. 2005, 280, 23815-23819.

146. Legler, G. Glycoside hydrolases: mechanistic information from studies with reversible and irreversible inhibitors. Adv. Carbohydr. Chem. Biochem. 1990, 48, 319-384.

147. Freeman, S.; Hudlicky, T. New Oligomers of Conduritol-F and muco-Inositol. Synthesis and Biological Evaluation as Glycosidase Inhibitors. Bioorg. Med. Chem. Lett. 2004, 14,1209-1212.

148. Witte, M. D.; Walvoort, M. T. C.; Li, K.-Y.; Kallemeijn, W. W.; Donker-Koopman, W. E.; Boot, R. G.; Aerts, J. M. F. G.; Codée, J. D. C.; Marel, G. A. v. d.; Overkleeft, H. S. Activity-Based Profiling of Retaining $\beta$ Glucosidases: A Comparative Study. ChemBioChem 2011, 12, 1263-1269; see also, M. D. Witte, et al. Ultrasensitive in situ visualization of active glucocerebrosidase molecules. Nature Chem. Biol. 2010, 6, $906-913$. 149. D'Antona, N.; Morrone, R.; Bovicelli, P.; Gambera, G.; Kubíc ` , D.; Martínková, L. A Novel Chemomultienzymatic Synthesis of Bioactive Cyclophellitol and epi-Cyclophellitol in both Enantiopure Forms. Tetrahedron: Asymm. 2010, 21, 2448-2454.

150. Wang, Y.; Ma, L.; Li, Z.; Du, Z.; Liu, Z.; Qin, J.; Wang, X.; Huang, Z.; Gu, L.; Chen, A. S. C. Synergetic Inhibition of Metal Ions and Genistein on $\alpha$-Glucosidase. FEBS Letters 2004, 576, 46-50.

151. Johnson, L. L.; Houston, T. A. A Drug Targeting Motif for Glycosidase Inhibitors: an IminosugarBoronate shows Unexpectedly Selective $\beta$-Galactosidase Inhibition. Tetrahedron Lett. 2002, 43, 8905-8908.

152. Eivazi, F.; Tabatabai, M. A. Factors Affecting Glucosidase and Galactosidase Activities in Soils. Soil Biol. Biochem. 1990, 22, 891-897.

153. Yasumatsu, N.; Yoshikawa, Y.; Adachi, Y.; Sakurai, H. Antidiabetic Copper(II)-picolinate: Impact of the First Transition Metal in the Metallopicolinate Complexes. Bioorg. Med. Chem. 2007, 15, 4917-4922.

154. Sakurai, H.; Katoh, A.; Yoshikawa, Y. Chemistry and Biochemistry of Insulin-Mimetic Vanadium and Zinc Complexes. Trial for Treatment of Diabetes Mellitus. Bull. Chem. Soc. Jpn. 2006, 79, 1645-1664.

155. Yoshikawa, Y.; Hirata, R.; Yasui, H.; Sakurai, H. $\alpha$-Glucosidase Inhibitory Effect of Anti-diabetic Metal Ions and their Complexes. Biochimie 2009, 91,1339-1341.

156. Blüchel, C.; Ramana, C. V.; Vasella, A. Synthesis of Monosaccharide-Derived Spirocyclic Cyclopropylamines and Their Evaluation as Glycosidase Inhibitors. Helv. Chim. Acta 2003, 86, 2998-3036.

157. Cossar, P. J.; Hizartzidis, L.; Simone, M. I.; McCluskey, A.; Gordon, C. P. The expanding utility of continuous flow hydrogenation. Org. Biomol. Chem. 2015, 13, 7119-7130.

158. Hattie, M.; Cekic, N.; Debowski, A. W.; Vocadlo, D. J.; Stubbs, K. A. Modifying the phenyl group of PUGNAc: reactivity tuning to deliver selective inhibitors for N-acetyl-D-glucosaminidases. Org. Biomol. Chem. 2016, 14, 3193-3197.

159. Jiang, J.; Artola, M.; Beenakker, T. J. M.; Schröder, S. P.; Petracca, R.; de Boer, C.; Aerts, J. M. F. G.; van der Marel, G. A.; Codée, J. D. C.; Overkleeft, H. S. The Synthesis of Cyclophellitol-Aziridine and Its 
Configurational and Functional Isomers. Eur. J. Org. Chem. 2016, 3671-3678.

160. Tankrathok, A.; Iglesias-Fernandez, J.; Williams, R. J.; Pengthaisong, S.; Baiya, S.; Hakki, Z.;

Robinson, R. C.; Hrmova, M.; Rovira, C.; Williams, S. J.; Ketudat Cairns, J. R. A Single Glycosidase Harnesses Different Pyranoside Ring TransitionState Conformations for Hydrolysis of Mannosides and Glucosides. ACS Catal. 2015, 5, 6041-6051

161. Jin, Y.; Petricevic, M.; John, A.; Raich, L.; Jenkins, H.; De Souza, L. P.; Cuskin, F.; Gilbert, H. J.; Rovira, C.; Goddard-Borger, E. D.; Williams, S. J.; Davies, G. J. A $\beta$-Mannanase with a Lysozyme-like Fold and a Novel Molecular Catalytic Mechanism. ACS Cent. Sci. 2016, 2, 896-903.

162. Kallemeijn, W. W.; Scheij, S.; Voorn-Brouwer, T. M.; Witte, M. D.; Verhoek, M.; Overkleeft, H. S.; Boot, R. G.; Aerts, J. M. F. G. Endo- $\beta$-Glucosidase Tag Allows Dual Detection of Fusion Proteins by Fluorescent Mechanism-Based Probes and Activity Measurement ChemBioChem 2016, 17, 1698 - 1704.

163. Thompson, A. J.; Williams, R. J.; Hakki, Z.; Alonzi, D. S.; Wennekes, T.; Gloster, T. M.; Songsrirote, K.; Thomas-Oates, J. E.; Wrodnigg, T. M.; Spreitz, J.; Stutz, A. E.; Butters, T. D.; Williams, S. J.; Davies, G. J. Proc. Natl. Acad. Sci. U. S. A. 2012, 109, 781-786.

164. Speciale, G.; Thompson, A. J.; Davies, G. J. Williams, S. J. Curr. Opin. Struct. Biol. 2014, $28,1-13$.

165. Petricevik, M.; Sobala, L. F.; Fernandes, P. Z.; Raich, L.; Thompson, A. J.; Bernardo-Seisdedos, G.; Millet, O.; Zhu, S.; Sollogoub, M.; Jimenez-Barbero, J.; Rovira, C.; Davies, G. J. Williams, S. J. J. Am. Chem. Soc. 2017, 139, 1089-1097. 


\section{TABLES}

Table I. $\mathrm{K}_{\mathrm{i}}$ Values $(\mu \mathrm{M})$ of derivatives 15-18 and for the parent alkaloids DMDP 13 and australine $\mathbf{1 4}$ against various glycosidases. ${ }^{55}$

\begin{tabular}{|c|c|c|c|c|c|c|c|c|}
\hline 寄 & 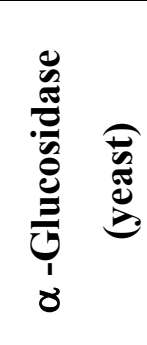 & 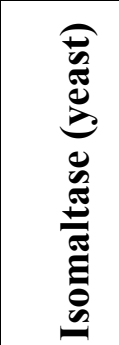 & 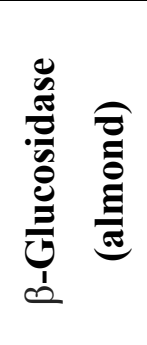 & $\begin{array}{l}\beta \text { - } \\
\text { Glucosidase/ } \\
\beta- \\
\text { Galactosidase } \\
\text { (bovine liver) }\end{array}$ & 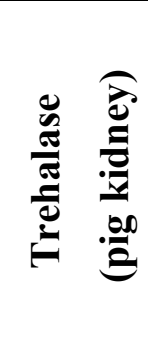 & 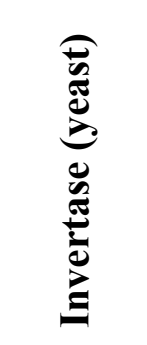 & 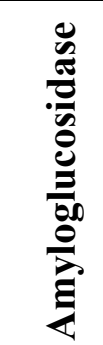 & 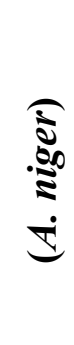 \\
\hline 13 & 0.73 & 2.5 & 1.7 & 3.3 & 355 & 2.9 & 2.1 & \\
\hline 14 & $\mathrm{NI}^{\mathrm{a}}$ & $\mathrm{ND}^{\mathrm{b}}$ & NI & ND & ND & 28 & 1.5 & \\
\hline 15 & 72 & 28 & 9.2 & 39 & NI & $>1000$ & NI & \\
\hline 16 & NI & 251 & NI & NI & 20 & NI & 249 & \\
\hline 17 & 132 & 29 & 340 & 644 & $\mathrm{NI}$ & NI & $\mathrm{NI}$ & \\
\hline 18 & 408 & 72 & 433 & 347 & NI & NI & NI & \\
\hline
\end{tabular}

${ }^{\mathrm{a}} \mathrm{NI}=$ no inhibition detected; ${ }^{\mathrm{b}} \mathrm{ND}=$ not determined.

Table II. IC $\mathrm{IC}_{50}$ Values $(\mu \mathrm{M})$ of thiosugar sulfonium salts and related compounds against $\alpha$ glucosidases. ${ }^{111}$

\begin{tabular}{|l|l|l|l|}
\hline \multirow{2}{*}{ Compound } & \multicolumn{3}{|c|}{$\boldsymbol{\alpha}$-Glucosidase (rat intestinal) } \\
\cline { 2 - 4 } & maltase & Sucrase & isomaltase \\
\hline $\mathbf{4 0}$ & 5.1 & 1.0 & 1.4 \\
$\mathbf{4 1}$ & 4.3 & 2.9 & 1.0 \\
$\mathbf{4 2}$ & 1.3 & 0.3 & 1.0 \\
$\mathbf{4 5}$ & $>384$ & 90 & 6.5 \\
$\mathbf{4 6}$ & $>329$ & $>329$ & $>329$ \\
$\mathbf{4 7}$ & 105 & $>384$ & 53 \\
Voglibose & $1.2^{\mathrm{b}}$ & $0.2^{\mathrm{b}}$ & $2.1^{\mathrm{b}}$ \\
Acarbose & $1.7^{\mathrm{a}}$ & $1.5^{\mathrm{a}}$ & $646^{\mathrm{a}}$ \\
\hline
\end{tabular}

${ }^{\mathrm{a} F r o m}$ ref. 115. ${ }^{\mathrm{b}}$ From ref. 113.

Table III. IC I0 $_{0}$ Values $(\mu \mathrm{M})$ of thiosugar sulfonium salts 3 and 32, and D-ATA 48 against $\alpha$ glucosidases. ${ }^{93}$ 


\begin{tabular}{|l|l|l|l|l|l|}
\hline Compound & \multicolumn{4}{|l|}{$\alpha$-Glucosidase } \\
\cline { 2 - 6 } & rice & $\begin{array}{l}\text { rat } \\
\text { maltase }\end{array}$ & $\begin{array}{l}\text { rat } \\
\text { isomaltase }\end{array}$ & $\begin{array}{l}\text { rat } \\
\text { sucrase }\end{array}$ & $\begin{array}{l}\text { human } \\
\text { lysosome }\end{array}$ \\
\hline $\mathbf{3}$ & 2.6 & 2.4 & 5.7 & 2.2 & 0.34 \\
$\mathbf{3 2}$ & 8.6 & 10 & 0.64 & 5.2 & 4.4 \\
$\mathbf{4 8}$ & 220 & 290 & 1000 & $\mathrm{NI}$ & $\mathrm{NI}$ \\
\hline
\end{tabular}

Table IV. IC 50 Values $(\mu \mathrm{M})$ of 3'- $O$-alkylated salacinol derivatives 33-36 and positive controls voglibose and acarbose against $\alpha$-glucosidases. ${ }^{113}$

\begin{tabular}{|l|l|l|l|}
\hline Compound & \multicolumn{3}{|c|}{$\alpha$-Glucosidase (rat intestinal) } \\
\hline & maltase & isomaltase & sucrase \\
\hline $\mathbf{3 3}$ & 5.3 & 0.39 & 0.46 \\
$\mathbf{3 4}$ & 1.7 & 0.27 & 0.12 \\
$\mathbf{3 5}$ & 1.0 & 0.95 & 1.3 \\
$\mathbf{3 6}$ & 0.44 & 0.14 & 0.32 \\
Voglibose & 1.2 & 2.1 & 0.2 \\
Acarbose & $1.7^{\mathrm{a}}$ & $646^{\mathrm{a}}$ & $1.5^{\mathrm{a}}$ \\
\hline
\end{tabular}

${ }^{a}$ From ref. 115. 